\title{
Characterisation and Traceability of Calcium Carbonate from the Seaweed Lithothamnium calcareum
}

\author{
Rosana Pereira da Silva ${ }^{1, * \mathbb{D}}$, Giovanna Sayuri Domingues Kawai ${ }^{2}$, Fabio Ramos Dias de Andrade ${ }^{2} \mathbb{D}$, \\ Vinicius Danilo Nonato Bezzon ${ }^{3}(\mathbb{D})$ and Humberto Gomes Ferraz ${ }^{1}$ \\ 1 Faculty of Pharmaceutical Sciences, University of São Paulo, Av. Prof. Lineu Prestes, 580, Butantã, \\ São Paulo CEP 05508-900, Brazil; sferraz@usp.br \\ 2 Institute of Geosciences, University of São Paulo, Rua do Lago 562, São Carlos, \\ São Paulo CEP 05508-080, Brazil; giovanna.kawai@usp.br (G.S.D.K.); dias@usp.br (F.R.D.d.A.) \\ 3 Centre for Natural and Human Sciences (CCNH), Federal University of ABC (UFABC), Av. dos Estados, \\ 5001, Santo André, São Paulo CEP 09210580, Brazil; vinicius.bezzon@gmail.com \\ * Correspondence: rosanapesi@usp.br; Tel.: +55-11-3091-8954
}

Citation: da Silva, R.P.; Kawai, G.S.D.; Andrade, F.R.D.d.; Bezzon, V.D.N.; Ferraz, H.G. Characterisation and Traceability of Calcium Carbonate from the Seaweed Lithothamnium calcareum. Solids 2021, 2, 192-211. https://doi.org/10.3390/ solids2020013

Academic Editor: Guido Kickelbick

Received: 24 February 2021

Accepted: 6 April 2021

Published: 6 May 2021

Publisher's Note: MDPI stays neutral with regard to jurisdictional claims in published maps and institutional affiliations.

Copyright: (c) 2021 by the authors. Licensee MDPI, Basel, Switzerland. This article is an open access article distributed under the terms and conditions of the Creative Commons Attribution (CC BY) license (https:// creativecommons.org/licenses/by/ $4.0 /)$.

\begin{abstract}
Calcium carbonate $\left(\mathrm{CaCO}_{3}\right)$ from the seaweed Lithothamnium calcareum is a suitable dietary supplement for the prevention of osteoporosis, due to its chemical composition. This study compared $\mathrm{CaCO}_{3}$ from $\mathrm{L}$. calcareum to $\mathrm{CaCO}_{3}$ from oyster shell and inorganic minerals that are already used in the pharmaceutical industry. The Rietveld refinement of the XRD showed that the mineral fraction of L. calcareum is composed of aragonite (50.3 wt \%), magnesian calcite (45.3 wt \%), calcite (4.4 $\mathrm{wt} \%)$, comin contrast to oyster shell and inorganic minerals, which contain only calcite. The morphology of L. calcareum carbonate particles is granular xenomorphic, which is distinct from the scalenohedral form of inorganic calcite and the fibrous and scale-like fragments of oyster shell. The crystal structures of aragonite and magnesian calcite, present in L. calcareum, have higher contents of oligoelements than the pure calcite in other materials. The isotopic composition (stable isotopes of carbon and oxygen) is heavy in the $\mathrm{CaCO}_{3}$ from L. calcareum $\left(\delta^{13} \mathrm{C}=1.1 \%\right.$; $\delta^{18} \mathrm{O}=-0.1 \%$ o and oyster shell $\left(\delta^{13} \mathrm{C}=-4 \%\right.$; $\delta^{18} \mathrm{O}=-2.8 \%$ o $)$ in marked contrast to the much lighter isotopic composition of inorganic mineral $\mathrm{CaCO}_{3}\left(\delta^{13} \mathrm{C}=-19.2 \% ; \delta^{18} \mathrm{O}=-26.3 \%\right.$ o $)$. The differences indicated above were determined through principal component analysis, where the first and second principal components are sufficient for the clear distinction and traceability of $\mathrm{CaCO}_{3}$ sources.
\end{abstract}

Keywords: calcium carbonate; Lithothamnium calcareum; traceability of $\mathrm{CaCO}_{3}$ sources; trace elements in calcium carbonates

\section{Introduction}

Calcium carbonate $\left(\mathrm{CaCO}_{3}\right)$ is a mineral that is widely distributed in nature, originating from both biological sources [1-4] and inorganic mineralogical processes $[5,6] . \mathrm{CaCO}_{3}$ is used in the production of civil construction materials [7], as well as in agriculture, food, cosmetics, and pharmaceuticals $[8,9]$.

In biomedicine, $\mathrm{CaCO}_{3}$ can be used in the form of nanoparticles to create drug delivery systems for cancer treatment [10]. In the pharmaceutical industry, $\mathrm{CaCO}_{3}$ is commonly used as a low-cost excipient [11,12]. In addition, an interesting use of $\mathrm{CaCO}_{3}$ is as an active ingredient in food supplements to prevent osteoporosis [13,14].

Osteoporosis is a bone metabolic disease characterised by low bone strength, leading to fragility and the risk of fracture, which is observed globally [15,16]. For optimal performance and processing capacity of a pharmaceutical formulation, it is essential to perform adequate physical and chemical characterisation of its active ingredient [17].

Biogenic $\mathrm{CaCO}_{3}$ from seaweed has been increasingly used in dietary supplementation to prevent osteoporosis $[18,19]$. Lithothamnium calcareum (L. calcareum) is a seaweed from the Corallinacea family, with a typical reddish colour, which crystallises calcium carbonate 
in its cell walls $[1,20,21]$ and, additionally, is rich in trace elements [20,22]. Products containing L. calcareum $\mathrm{CaCO}_{3}$ are used in several countries [23] due to its bioavailability and beneficial anabolic effects on bone calcification in animals $[19,24]$ compared to other $\mathrm{CaCO}_{3}$ sources [25].

There is a paucity of the literature on the physical and chemical characterisation of L. calcareum $\mathrm{CaCO}_{3}$. The published data focus on its chemical composition, especially with regard to trace elements $[22,26,27]$. However, aspects such as the flow properties, polymorphism, morphology and compositional variations on a microscopic scale, surface area and porosity are fundamental parameters for the production of $\mathrm{CaCO}_{3}$ tablets [28].

Another aspect that is rarely explored in the literature is the composition of the rare earth elements (REE), trace elements and stable isotopes [29] of $\mathrm{CaCO}_{3}$. The study of their composition allows for the distinction of carbonates from different origins and can be a useful tool for the traceability of inputs used in the pharmaceutical industry [30,31].

Thus, considering the gap in the scientific literature regarding the characterisation and traceability of $L$. calcareum $\mathrm{CaCO}_{3}$, this study aims to accurately characterise the methods of powder flow, surface area and porosity, thermal analysis, scanning electron microscopy and energy-dispersive spectroscopy, X-ray diffraction, chemical analysis and stable isotopes of L. calcareum $\mathrm{CaCO}_{3}$ in terms of its physical, chemical, mineralogical and isotopic properties $(\mathrm{C}, \mathrm{O})$ using, for comparison purposes, $\mathrm{CaCO}_{3}$ from oyster shell and inorganic minerals.

\section{Results and Discussion}

L. calcareum $\mathrm{CaCO}_{3}$ showed a lower Carr index (CI) and Hausner ratio (HR) than the other $\mathrm{CaCO}_{3}$ samples used in the pharmaceutical industry, with all the samples having non-ideal flow characteristics (Table 1). Poor flow characteristics may be partly related to the distribution of particle size and porosity, among other factors [32]. In L. calcareum $\mathrm{CaCO}_{3}$, there may have been a greater interaction between the particles as a consequence of their morphology. The flow of $\mathrm{CaCO}_{3}$ particles is compromised by the cleavage of crystals, which form particles of an anisotropic (rhombohedral) shape, deviating from the ideal spherical shape [33]. The smaller the particle size, the lower the CI and HR, which are features that distinguish L. calcareum $\mathrm{CaCO}_{3}$ from other carbonates [34,35]. As a result, during material processing, a deficient flow of powder in the compressing machine can significantly impact the final product, contributing to weight variability and influencing the quality of the tablets. In light of this, it is more appropriate to use the wet granulation process to obtain $\mathrm{CaCO}_{3}$ tablets for food supplements, whatever their source [36,37].

Table 1. Flow properties of $\mathrm{CaCO}_{3}$ samples: apparent density, compacted density, Carr index and Hausner ratio of Lithothamnium calcareum, inorganic mineral and oyster shell $\mathrm{CaCO}_{3}$ and \pm range $(\mathrm{n}=3)$.

\begin{tabular}{ccccc}
\hline Samples & Apparent Density $(\mathrm{g} / \mathrm{mL})$ & Compacted Density $(\mathrm{g} / \mathrm{mL})$ & Carr Index (\%) & Hausner Ratio \\
\hline L. calcareum $\mathrm{CaCO}_{3}$ & $0.49 \pm 0.01$ & $0.80 \pm 0.01$ & $38.75 \pm 0.01$ & $1.63 \pm 0.01$ \\
Inorganic mineral CaCO & $0.03 \pm 0.02$ & $43.40 \pm 0.02$ & $1.77 \pm 0.02$ \\
Oyster shell $\mathrm{CaCO}_{3}$ & $0.30 \pm 0.01$ & $1.32 \pm 0.02$ & $43.94 \pm 0.02$ & $1.78 \pm 0.02$ \\
\hline
\end{tabular}

The fluidity of $\mathrm{CaCO}_{3}$ is also related to its surface area and porosity. A decrease in the pore size of $\mathrm{L}$. calcareum and oyster shell $\mathrm{CaCO}_{3}$ increases the compacted density of the material (Table 2), making the tablets fragile, brittle and easily chipped during large-scale production [33].

Table 2. Surface area, volume and pore size of Lithotthamnium calcareum, inorganic mineral and oyster shell $\mathrm{CaCO}_{3}$ samples.

\begin{tabular}{cccc}
\hline Sample & $\mathbf{A}_{\mathbf{( B E T )}}\left(\mathbf{m}^{\mathbf{2}} \cdot \mathbf{g}^{-\mathbf{1}}\right)$ & $\mathbf{V}_{\mathbf{p}}\left(\times \mathbf{1 0}^{-\mathbf{3}} \mathbf{c m}^{\mathbf{3}} \cdot \mathbf{g}^{-\mathbf{1}}\right)$ & Pore Size $(\AA)$ \\
\hline L. calcareum $\mathrm{CaCO}_{3}$ & 8.118 & 1.585 & 3.906 \\
Inorganic mineral CaCO & 3.829 & 9.746 \\
Oyster shell $\mathrm{CaCO}_{3}$ & 7.857 & 5.081 & 3.463 \\
\hline
\end{tabular}


In terms of porosity, L. calcareum $\mathrm{CaCO}_{3}$ had the characteristics of an ultra-microporous material, with a pore size of $<7 \AA$; the form shown in the literature for this type of material is slit or curled [38,39]. These characteristics can represent a mechanical interlock between the particles and influence the fluidisation of the material [32]. Figure 1 shows that L. calcareum $\mathrm{CaCO}_{3}$ had H3-type hysteresis [40]. The shape of a hysteresis loop depends on the sample's pore size. In fact, like the pore sizes, the hysteresis loop was dissimilar between the $\mathrm{CaCO}_{3}$ samples. A hysteresis loop means that the desorption and adsorption curves are not identical. However, type $\mathrm{H} 3$ indicates non-rigid particle aggregates and is related to capillary condensation of porous solids [41]. Inorganic mineral $\mathrm{CaCO}_{3}$ also showed a tendency towards $\mathrm{H} 3$-type hysteresis, while for oyster shell $\mathrm{CaCO}_{3}$, we did not identify a hysteresis characteristic.
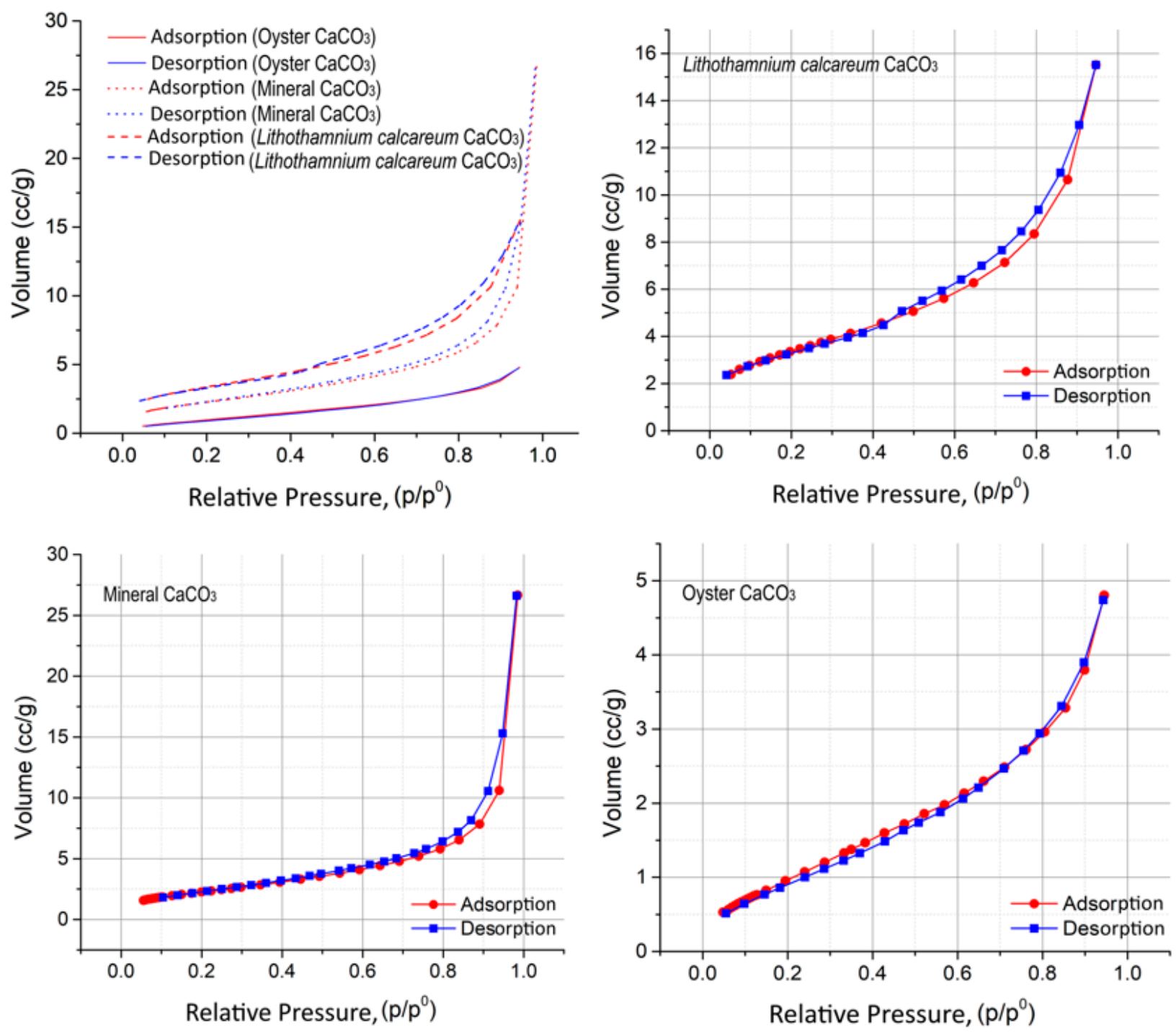

Figure 1. Profiles of adsorption and desorption of type III isotherms. The first graph represents the comparative profiles of the $\mathrm{CaCO}_{3}$ samples according to the scales.

Microporous materials are classified according to the International Union of Pure and Applied Chemistry (IUPAC), which considers materials with pore sizes between 7 and $20 \AA$ as microporous and those with a pore size $<7 \AA$ as ultra-microporous [42]. Oyster shell $\mathrm{CaCO}_{3}$ was ultra-microporous like L. calcareum $\mathrm{CaCO}_{3}$, while inorganic mineral $\mathrm{CaCO}_{3}$ was microporous. 
Ultra-microporous and microporous materials give rise to a type III isotherm, i.e., point $\mathrm{B}$ in relative pressure $\left(p / p^{0}\right)$ is not determined. The three $\mathrm{CaCO}_{3}$ samples had type III isotherms, and since gas molecules have a greater affinity for one another, the isotherms were not common [43]. We extracted data from the angular coefficient line of L. calcareum in which the constant $(C)$ was 75.0 i.e., a characteristic of adsorbate molecules with significant interactions between them. The linear coefficient of the L. calcareum $\mathrm{CaCO}_{3}$ sample was 0.999. The inorganic mineral and oyster shell $\mathrm{CaCO}_{3}$ samples showed linear coefficients of 0.999 and 0.998 , respectively, and each had a different value of $\mathrm{C}$-inorganic mineral $\mathrm{CaCO}_{3}$ had $\mathrm{C}=52.28$, while oyster shell $\mathrm{CaCO}_{3}$ had $\mathrm{C}=15.90$. In general, a microporous material has a pore-filling mechanism with adsorption occurring instantaneously [40], but this behaviour occurred only in the L. calcareum and oyster shell $\mathrm{CaCO}_{3}$ samples, which showed similar profiles, as seen in the graph of volume versus $p / p^{0}$ (Figure 1).

L. calcareum $\mathrm{CaCO}_{3}$ had the largest surface area compared with other samples and, consequently, a smaller pore volume, in addition to nitrogen adsorption and desorption isotherms similar to those observed by Xia et al. [44]. Inorganic mineral $\mathrm{CaCO}_{3}$ had surface area, pore volume and adsorption and desorption isotherm values similar to those of L. calcareum $\mathrm{CaCO}_{3}$, while the values of oyster shell $\mathrm{CaCO}_{3}$ were lower than those of L. calcareum $\mathrm{CaCO}_{3}$.

The thermogravimetric profile of L. calcareum $\mathrm{CaCO}_{3}$ indicated decomposition by $\mathrm{CO}$ release at $670.9^{\circ} \mathrm{C}$ (Table 3 and Figure 2), a temperature consistent with data from the literature [45]. This decomposition event corresponds to the endothermic peak identified from differential thermal analysis (DTA) at the same temperature. The mass loss of L. calcareum $\mathrm{CaCO}_{3}$ was similar to that reported by Li et al. [46].

Table 3. Thermo-analytical results for Lithothamnium. calcareum, inorganic mineral, and oyster shell $\mathrm{CaCO}_{3}$.

\begin{tabular}{cccccccc}
\hline Samples & Event & $\begin{array}{c}\mathbf{T}_{\text {pico peak }} \\
\text { DTG }\left({ }^{\circ} \mathbf{C}\right)\end{array}$ & $\begin{array}{c}\mathbf{T}_{\text {initial }} \\
\left({ }^{\circ} \mathbf{C}\right)\end{array}$ & $\begin{array}{c}\mathbf{T}_{\text {onset }} \\
\left({ }^{\circ} \mathbf{C}\right)\end{array}$ & $\begin{array}{c}\mathbf{T}_{\text {final }} \\
\left({ }^{\circ} \mathbf{C}\right)\end{array}$ & $\begin{array}{c}\text { Weight } \\
\text { Loss (\%) }\end{array}$ & $\begin{array}{c}\mathbf{T}_{\text {peak }} \\
\text { DTA }\left({ }^{\circ} \mathbf{C}\right)\end{array}$ \\
\hline $\begin{array}{c}\text { L. calcareum } \mathrm{CaCO}_{3} \\
\text { Inorganic mineral CaCO }\end{array}$ & Decomposition & 720.3 & 587.0 & 670.9 & 757.1 & 40.4 & 727.3 \\
Oyster shell CaCO 3 & Decomposition & 731.9 & 572.0 & 668.9 & 760.3 & 39.9 & 736.8 \\
\hline
\end{tabular}

DTG, derived thermogravimetry; DTA, differential thermal analysis.

The oyster shell $\mathrm{CaCO}_{3}$ showed a slightly higher decomposition temperature than the L. calcareum $\mathrm{CaCO}_{3}$, and the mass loss and exothermic peak increased in magnitude.

Scanning electron microscopy (SEM) images of L. calcareum $\mathrm{CaCO}_{3}$ revealed xenomorphic crystals, where the external form was not intrinsically related to the crystal structure (Figure 3A). Crystals were granular, with a size range below $2 \mu \mathrm{m}$. Energy-dispersive spectroscopy (EDS) analysis (Figure 3B) revealed the presence of $\mathrm{Ca}$ and $\mathrm{Mg}$, which is consistent with the mineralogical analysis.

Inorganic mineral $\mathrm{CaCO}_{3}$ (Figure 4A) presented well-defined scalenohedral crystals, which are defined by crystallographic planes $[47,48]$. The crystal size range was below $1 \mu \mathrm{m}$, which was smaller than that of L. calcareum $\mathrm{CaCO}_{3}$. The EDS plot (Figure $4 \mathrm{~B}$ ) revealed the presence of calcium, carbon and oxygen as the major components. Oyster shell $\mathrm{CaCO}_{3}$ (Figure 5A) had a plate-like morphology, formed by fibrous particles on a $1 \mathrm{~nm}$ scale. EDS analysis (Figure 5B) indicates the presence of calcium. 

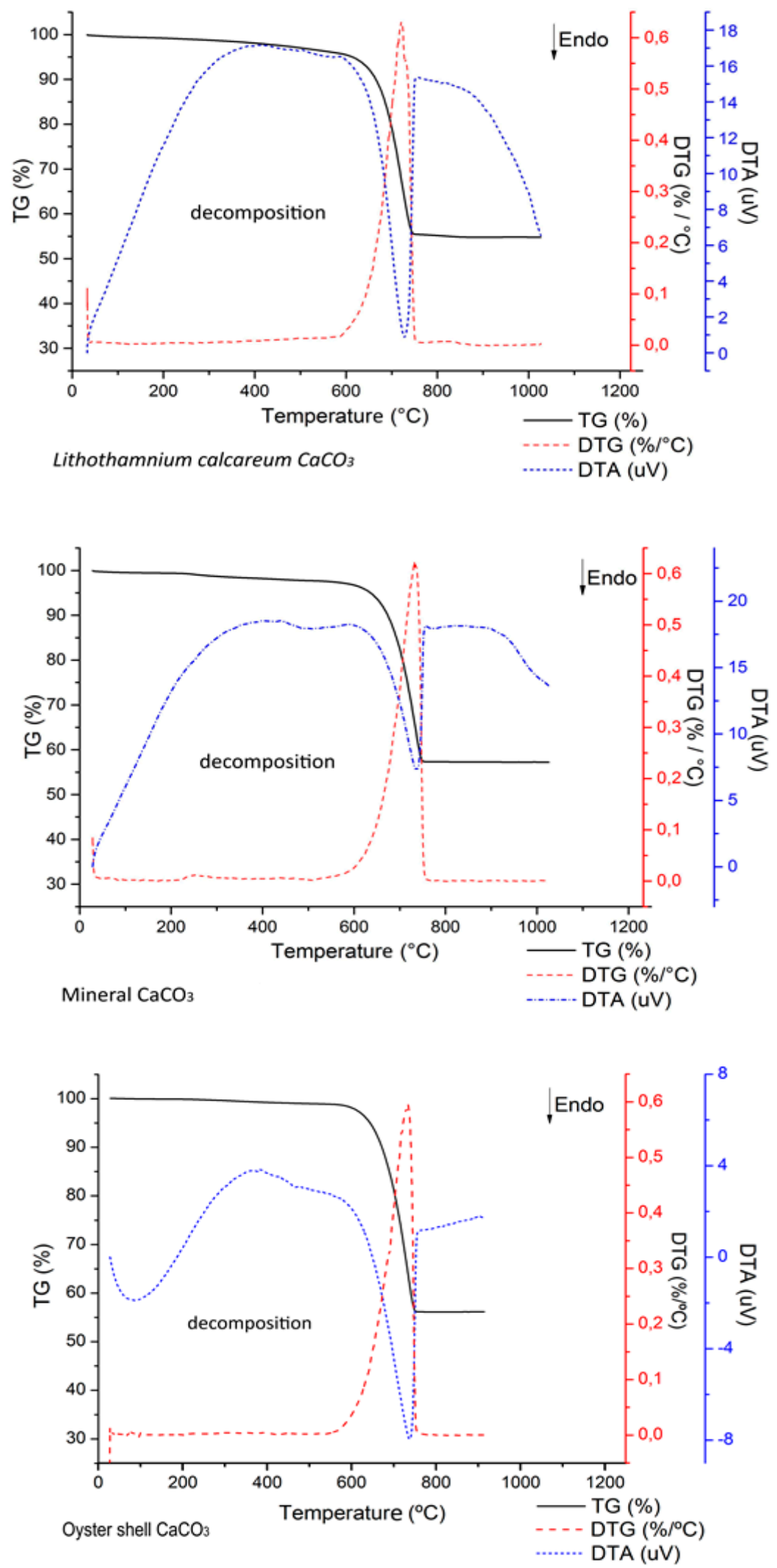

Figure 2. Thermogravimetry (TG) and DTG profiles of L. calcareum, inorganic mineral and oyster shell $\mathrm{CaCO}_{3}$. 


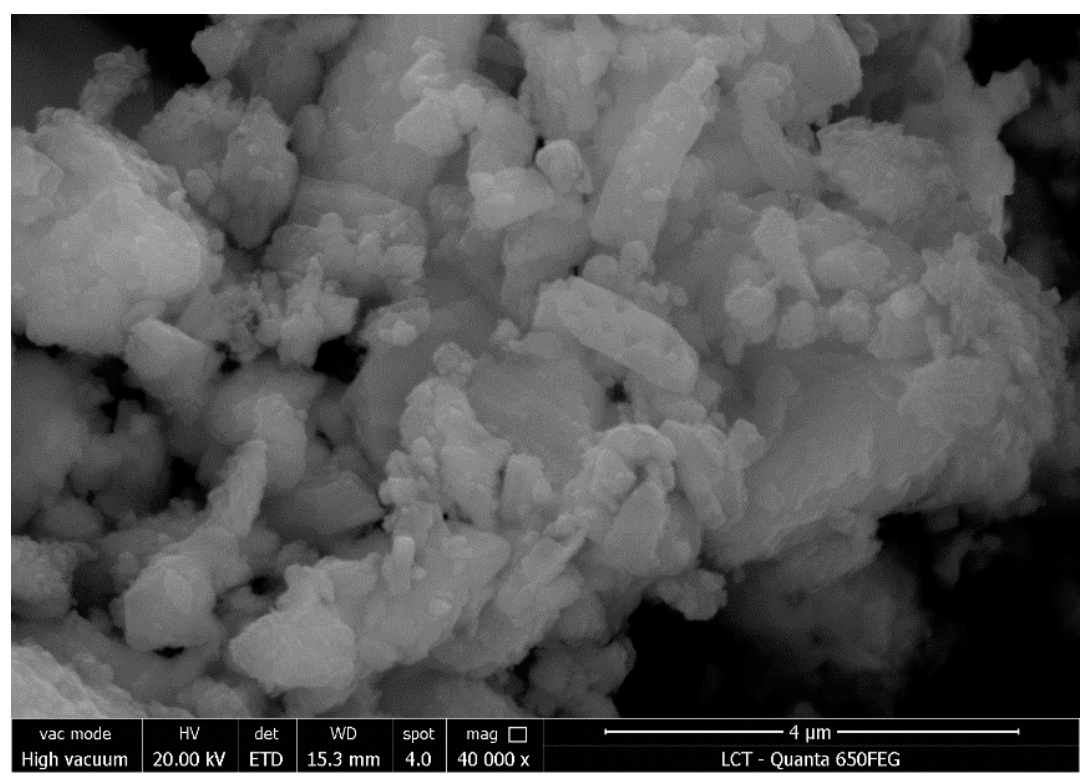

A

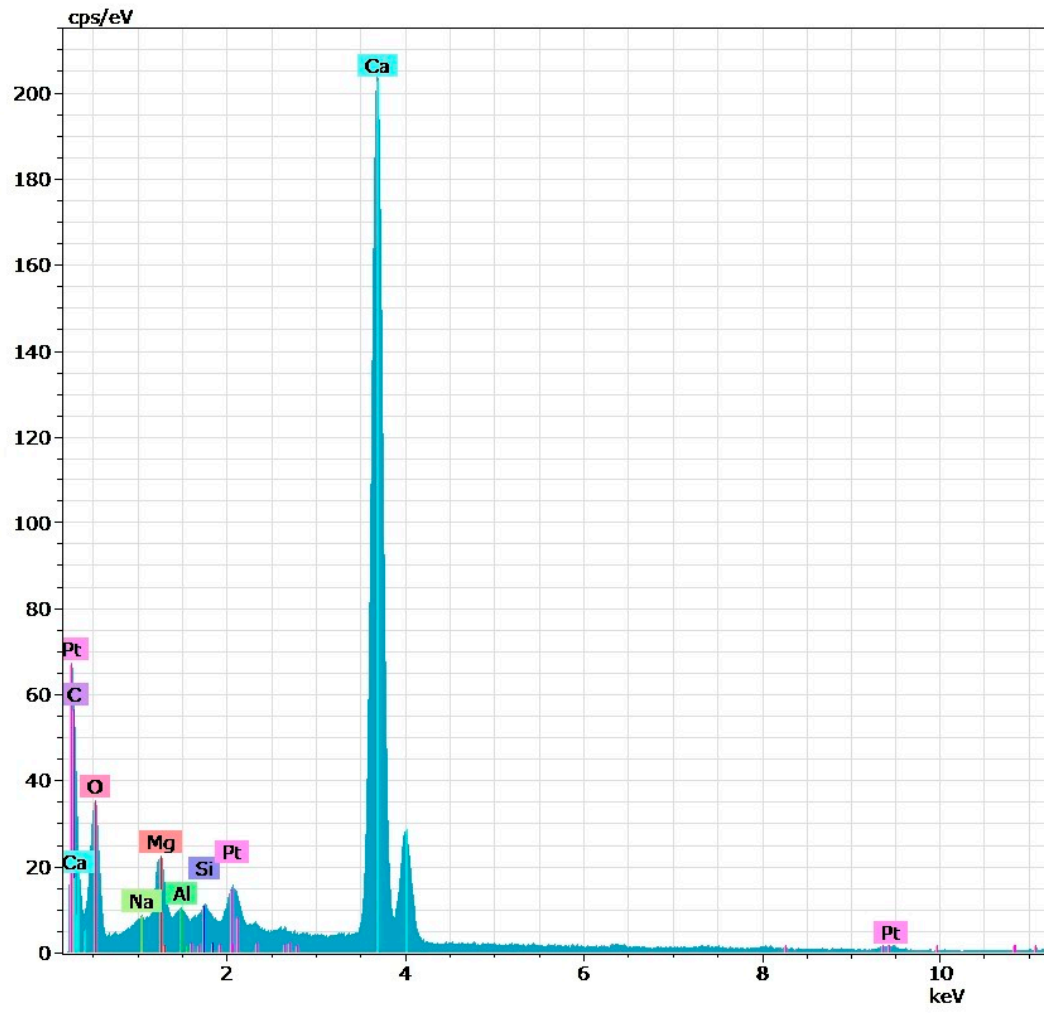

B

Figure 3. (A) Scanning electron microscopy (SEM) images with a magnification of $40,000 \times$ that demonstrated xenomorphic crystals for the L. calcareum $\mathrm{CaCO}_{3}$. (B) Energy-dispersive spectroscopy (EDS) analysis: from the information contained in the EDS spectrum it is possible to obtain quantitative information on the sample composition on a microscopic scale. In the spectrum, Platinum $(\mathrm{Pt})$, Carbon (C), Oxygen (O), Sodium (Na), Magnesium (Mg), Aluminium (Al) and Silicon (Si) were identified, in addition to Calcium (Ca). 


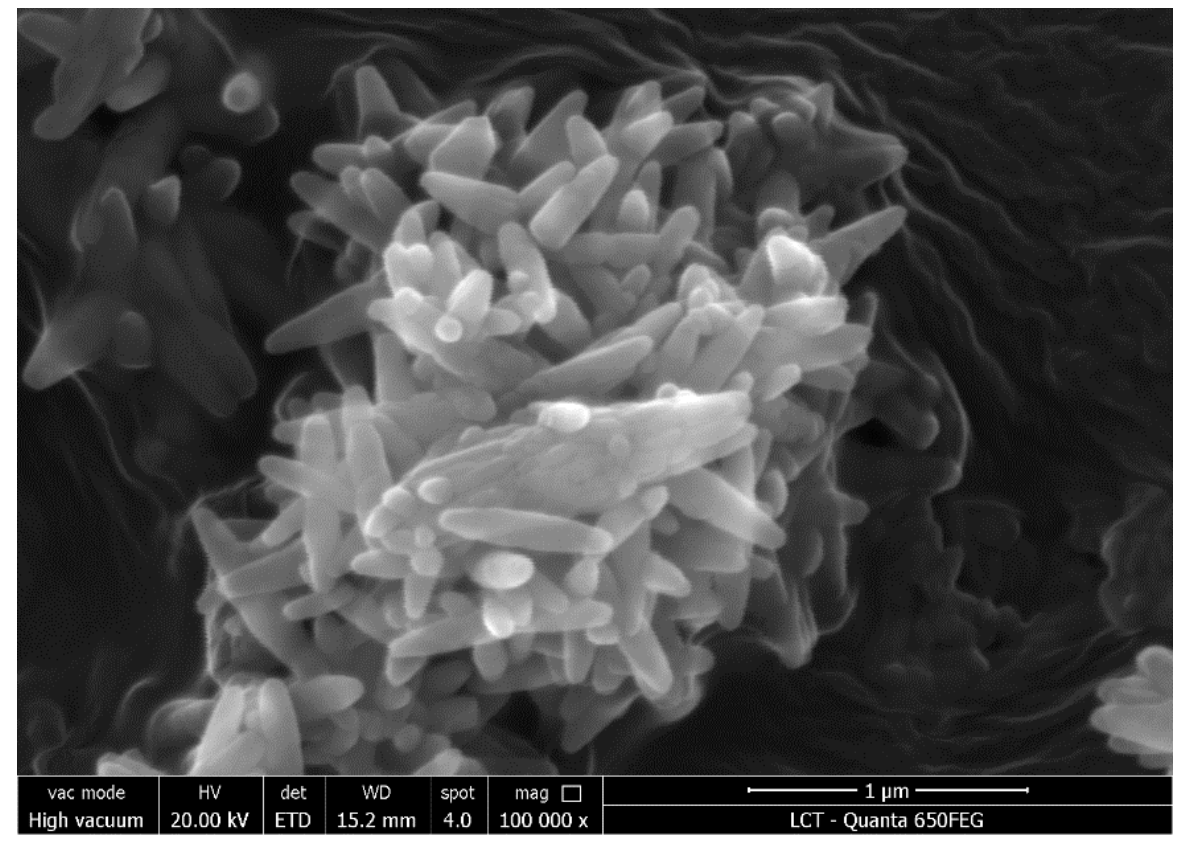

A

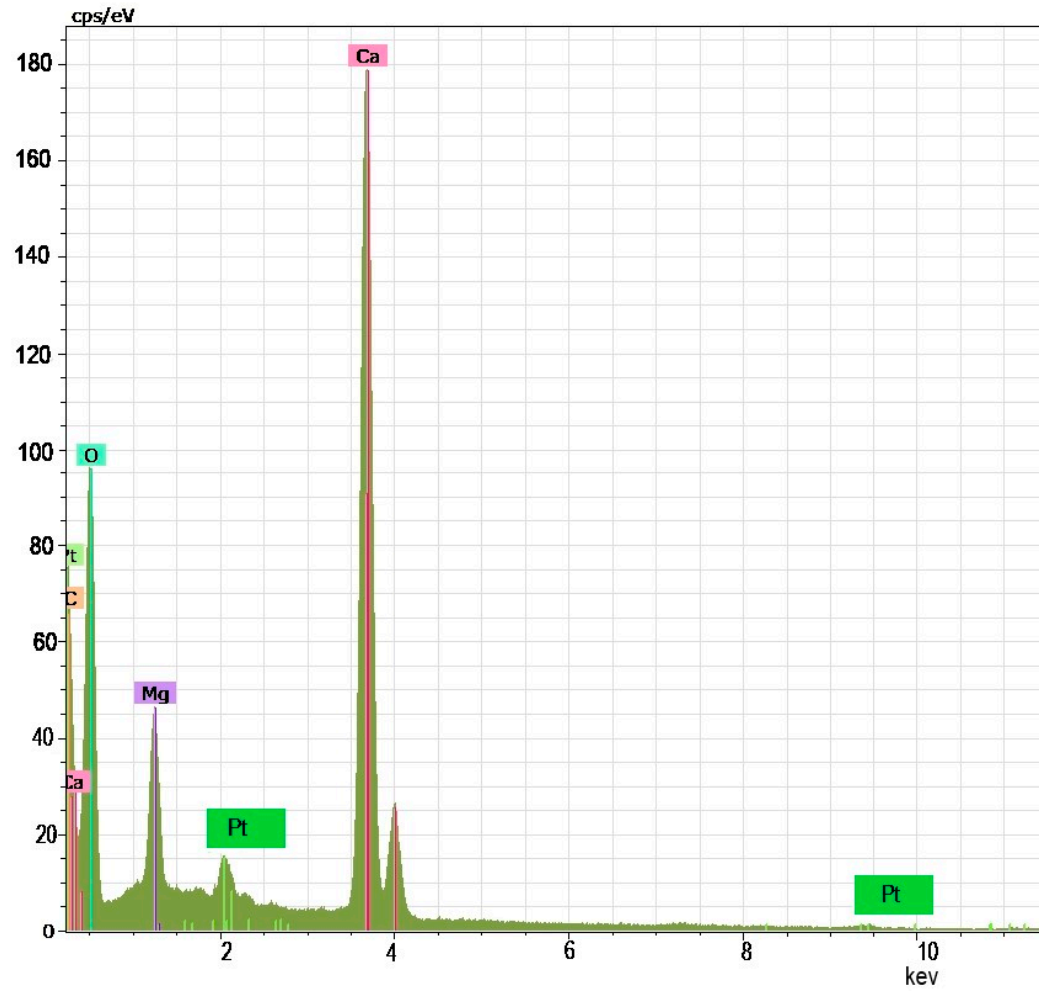

B

Figure 4. (A) Scanning electron microscopy (SEM) images with a magnification of $100,000 \times$ that demonstrated scalenohedral crystals for the inorganic mineral $\mathrm{CaCO}_{3}$. (B) Energy-dispersive spectroscopy (EDS) analysis: from the information contained in the EDS spectrum it is possible to obtain quantitative information on the sample composition on a microscopic scale. In the spectrum, Platinum $(\mathrm{Pt})$, Carbon $(\mathrm{C})$, Oxygen $(\mathrm{O})$ and Magnesium $(\mathrm{Mg})$ were identified, in addition to Calcium (Ca). 




A

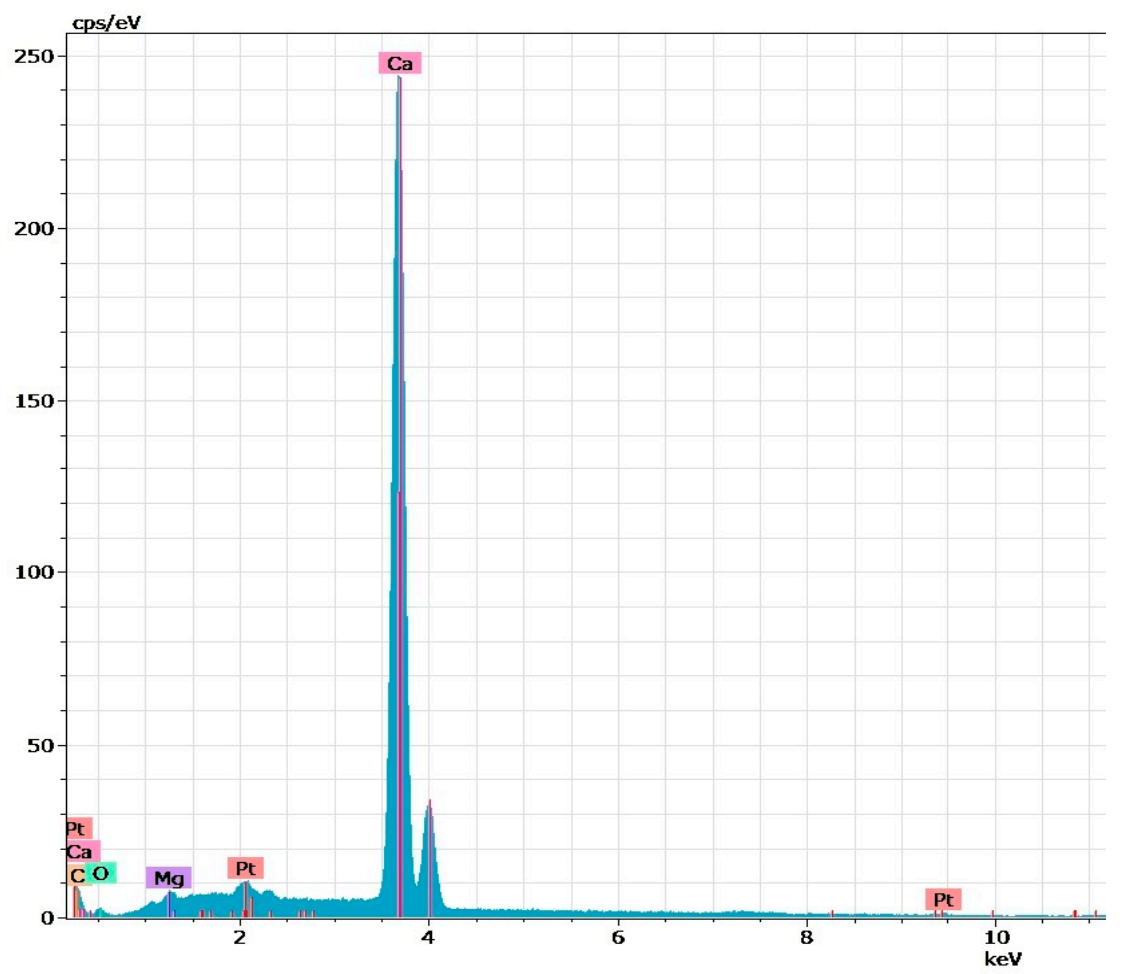

B

Figure 5. (A) Scanning electron microscopy (SEM) images with $2108 \times$ magnification that exhibited a plaque-like morphology with a fibrous appearance for the oyster shell $\mathrm{CaCO}_{3}$. (B) Energy-dispersive spectroscopy (EDS) analysis: from the information contained in the EDS spectrum it is possible to obtain quantitative information on the sample composition on a microscopic scale. In the spectrum, Platinum $(\mathrm{Pt})$, Carbon $(\mathrm{C})$, Oxygen $(\mathrm{O})$ and Magnesium $(\mathrm{Mg})$ were identified, in addition to Calcium (Ca).

X-ray diffractograms (Figure 6) of the three samples show that L. calcareum $\mathrm{CaCO}_{3}$ contains aragonite $(50.3 \mathrm{wt} \%)$, magnesian calcite $(45.3 \mathrm{wt} \%)$ and calcite $(4.4 \mathrm{wt} \%)$, as deter- 
mined by the XRD-Rietveld method. Inorganic mineral and oyster shell $\mathrm{CaCO}_{3}$ samples were composed solely of calcite.

(A)

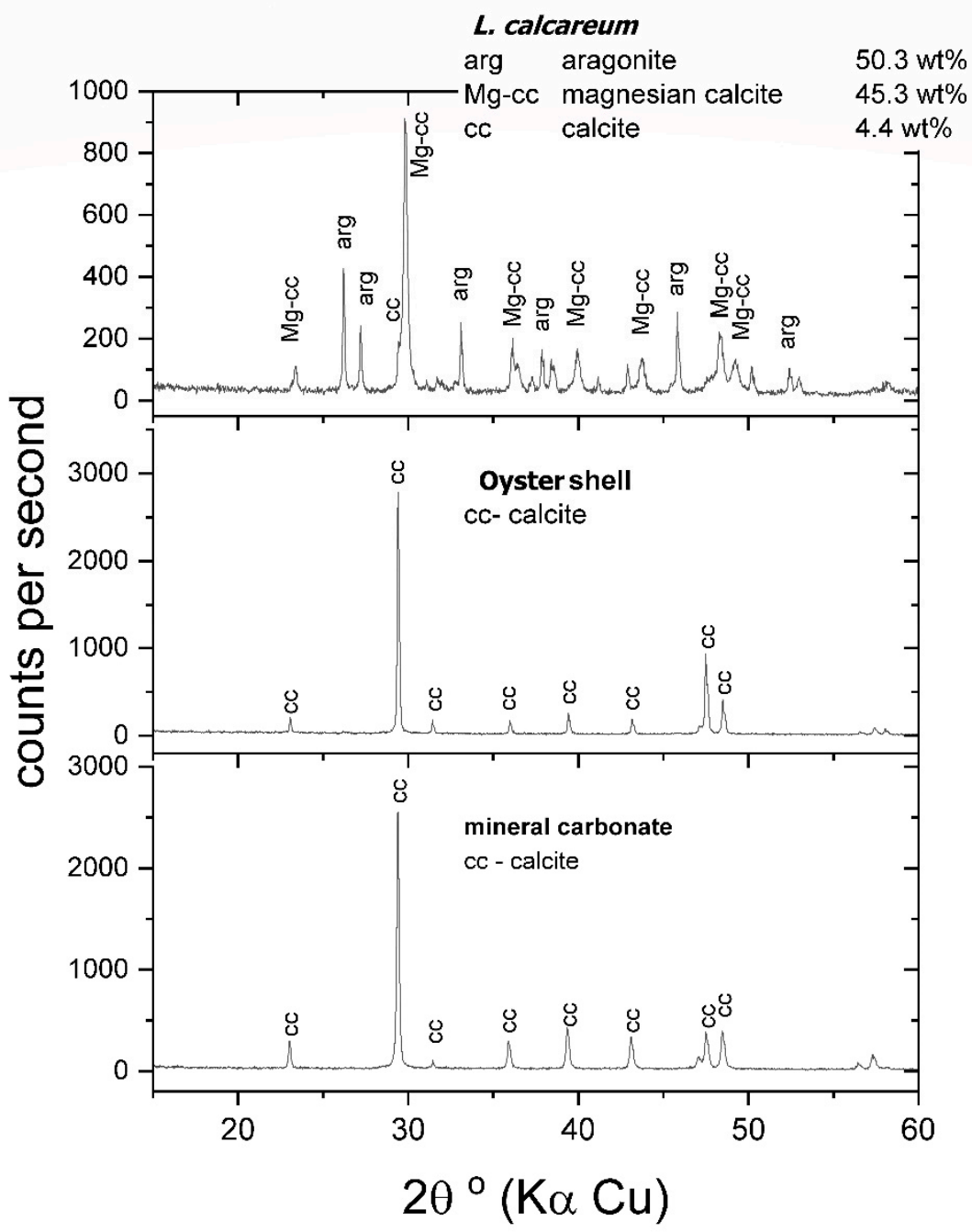

Figure 6. X-ray diffractograms profile of $\mathrm{CaCO}_{3}$ samples by the Rietveld method. In the refinement the theoretical density of the proportions distribution of the phases of L. calcareum (A) were aragonite: 2.94 g.cm ${ }^{-3}$, magnesian calcite: 2.84 g.cm ${ }^{-3}$ and calcite: 2.74 g.cm ${ }^{-3}$. The theoretical density recorded for inorganic mineral $\mathrm{CaCO}_{3}$ (B) was $2.72 \mathrm{~g} \cdot \mathrm{cm}^{-3}$ while for oyster shell $\mathrm{CaCO}_{3}(\mathbf{C})$ it was $2.71 \mathrm{~g} \cdot \mathrm{cm}^{-3}$.

The co-existence of calcite and magnesian calcite in L. calcareum $\mathrm{CaCO}_{3}$ suggests that either different biominerals are precipitated in different tissues or, alternatively, the biomineral composition is re-equilibrated in secondary processes, such as the lixiviation of recrystallisation. Magnesian calcite is thermodynamically unstable under ambient conditions. It is currently formed by several marine organisms, including red coralline algae. Mg intake in calcite reflects the $\mathrm{Mg} / \mathrm{Ca}$ ratio in seawater and is caused by the assemblage of amorphous crystallisation precursors [49]. In the XRD dataset presented (Figure 6), L. calcareum $\mathrm{CaCO}_{3}$ has less intense and broader peaks compared with inorganic mineral and oyster shell $\mathrm{CaCO}_{3}$, indicating a lower degree of crystallinity reducing the intensity and smaller crystallite size of L. calcareum magnesian calcite.

From the results obtained above, we constructed two-dimensional graphs of the main components (Figure 7). The two new variables created in the same dimension-principal component analysis (PCA1 and PCA2)-retained $100 \%$ of the information contained in the original variables. We also verified that PCA1 explained more than $70 \%$, while PCA2 explained $24.53 \%$ of the data variability, which was better defined only by pore size. For $L$. 
calcareum $\mathrm{CaCO}_{3}(\mathrm{~A})$, factor 1 interpreted the polymorphism, particle size and provided a well-represented surface area. In contrast, for inorganic $\mathrm{CaCO}_{3}(\mathrm{~B})$, the pore size stood out and, for oyster shell $\mathrm{CaCO}_{3}(\mathrm{C})$, factor 1 mainly interpreted calcium content and mass loss. The oyster shell $\mathrm{CaCO}_{3}$ sample was the most different from the other components, while the inorganic mineral $\mathrm{CaCO}_{3}$ sample (B) registered a larger group of variables. Thus, we compared the three groups, found that the samples differed in all variables, while those that stood out the most were calcium content and pore size, with values above 0.999 .
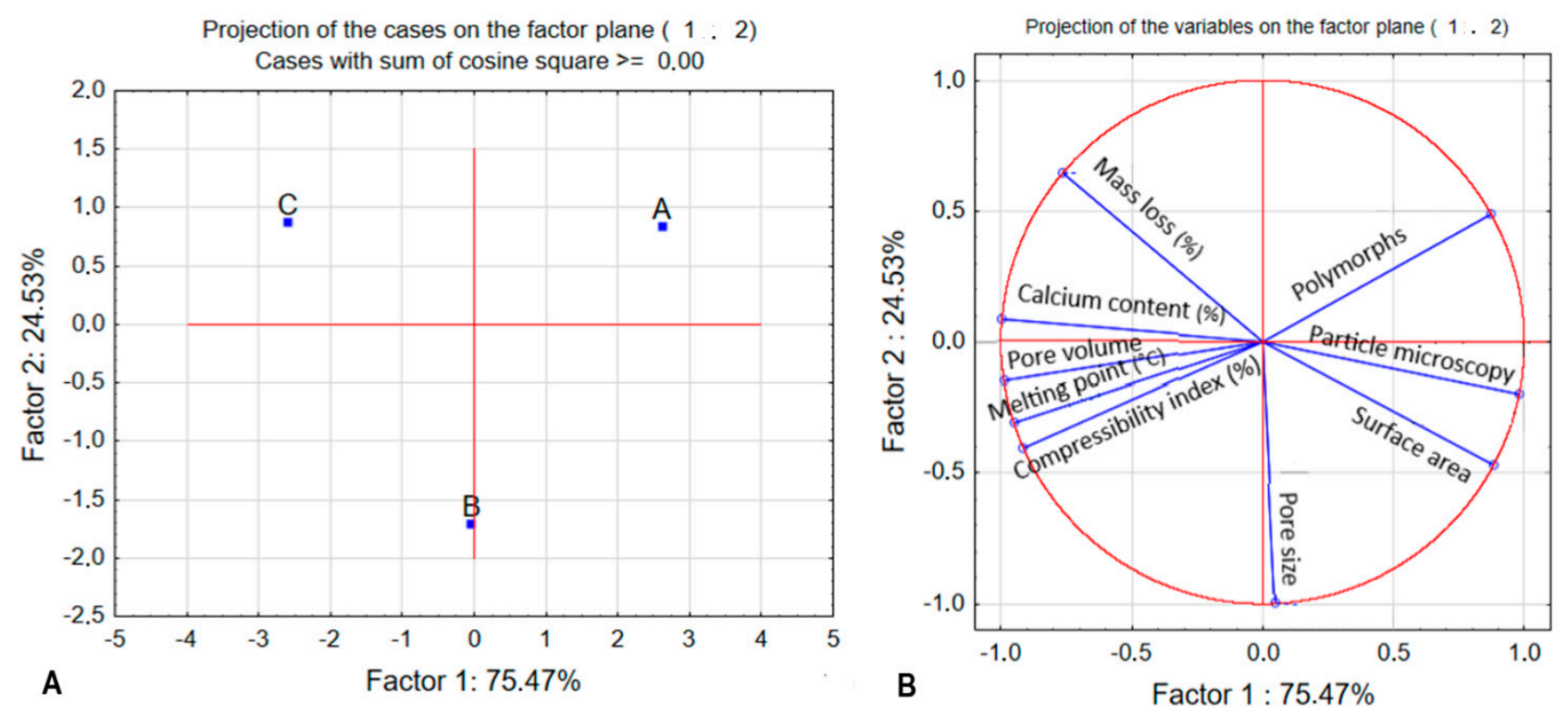

Figure 7. Main component graphs: (A) sample distribution of L. calcareum $\mathrm{CaCO}_{3}$ (A), inorganic mineral $\mathrm{CaCO}_{3}$ (B) and oyster shell $\mathrm{CaCO}_{3}(\mathrm{C})$ according to trends observed in multivariate analysis; (B) two-dimensional graph of main components. Both factors 1 and 2 correspond to $100 \%$ of the information contained in the original variables.

In terms of the chemical composition of the three $\mathrm{CaCO}_{3}$ samples (Table 4), the Sc, $\mathrm{Rb}, \mathrm{Y}, \mathrm{Zr}, \mathrm{Nb}, \mathrm{Cs}, \mathrm{Ba}, \mathrm{La}, \mathrm{Ce}, \mathrm{Pr}, \mathrm{Nd}, \mathrm{Sm}, \mathrm{Eu}, \mathrm{Gd}, \mathrm{Tb}, \mathrm{Dy}, \mathrm{Ho}, \mathrm{Er}, \mathrm{Tm}, \mathrm{Yb}, \mathrm{Lu}, \mathrm{Hf}, \mathrm{Pb}, \mathrm{Th}$ and $U$ content was low ( $<15 \mathrm{ppm})$, while the strontium (Sr) content was between 159.50 and $854.50 \mathrm{ppm}$. The presence of trace elements and the absence of toxicity represent advantages from a human health perspective [50,51]. The proportions of essential elements in food supplements are suitable for human consumption, since quantities of $<0.01 \%$ of body weight are necessary in the daily diet, except for $\mathrm{Al}, \mathrm{Cr}, \mathrm{Se}, \mathrm{Cu}, \mathrm{Mo}$ and $\mathrm{Pb}$, among others; high amounts of $\mathrm{Pb}$, for example, are considered toxic [52]. The largest number of trace elements was identified in L. calcareum $\mathrm{CaCO}_{3}$ compared with the other two samples, making them intrinsic characteristics related to the origin of the material. The presence of $\mathrm{Sr}$ in all three samples, but mainly in oyster shell $\mathrm{CaCO}_{3}$, is not a restrictive factor, as this element is not on the WHO list of toxic elements [53]. In the same way that $\mathrm{CaCO}_{3}$ plays a significant role in our body, trace elements also play an important role. Trace elements and their values are recognised by the European Food Safety Authority, which indicates how much the population should consume, in addition to calcium, regardless of their origin, to maintain a healthy diet [54]. 
Table 4. Content of trace elements (ppm) of samples (in duplicate) of L. calcareum, inorganic mineral and oyster shell $\mathrm{CaCO}_{3}$.

\begin{tabular}{ccccccc}
\hline Chemical Elements & \multicolumn{2}{c}{ L. calcareum } & \multicolumn{2}{c}{ Mineral $\mathrm{CaCO}_{3}$} & \multicolumn{2}{c}{ Oyster $\mathrm{CaCO}_{3}$} \\
\hline $\mathrm{Sc}$ & 0.50 & 0.49 & 0.07 & 0.07 & 0.03 & 0.03 \\
$\mathrm{Rb}$ & 0.87 & 0.91 & 0.33 & 0.33 & 0.11 & 0.11 \\
$\mathrm{Sr}$ & 291.0 & 307.8 & 158 & 161 & 868 & 842 \\
$\mathrm{Y}$ & 1.61 & 1.67 & 0.66 & 0.68 & 0.10 & 0.10 \\
$\mathrm{Zr}$ & 0.64 & 0.62 & 0.71 & 0.60 & 0.09 & 0.05 \\
$\mathrm{Nb}$ & 0.32 & 0.33 & 0.06 & 0.06 & 0.02 & 0.09 \\
$\mathrm{Cs}$ & 0.04 & 0.04 & $<0.01$ & $<0.01$ & $<0.01$ & $<0.01$ \\
$\mathrm{Ba}$ & 6.63 & 6.54 & 14.2 & 15.80 & $<0.50$ & 0.50 \\
$\mathrm{La}$ & 1.65 & 1.63 & 0.14 & 0.15 & 0.16 & 0.16 \\
$\mathrm{Ce}$ & 3.79 & 3.73 & $<0.01$ & $<0.01$ & $<0.01$ & $<0.01$ \\
$\mathrm{Pr}$ & 0.35 & 0.37 & 0.04 & 0.04 & 0.03 & 0.02 \\
$\mathrm{Nd}$ & 1.26 & 1.32 & 0.15 & 0.16 & 0.09 & 0.08 \\
$\mathrm{Sm}$ & 0.24 & 0.24 & 0.04 & 0.04 & 0.02 & 0.02 \\
$\mathrm{Eu}$ & 0.05 & 0.05 & 0.01 & 0.01 & $<0.01$ & $<0.01$ \\
$\mathrm{Gd}$ & 0.26 & 0.23 & 0.05 & 0.05 & 0.02 & 0.02 \\
$\mathrm{~Tb}$ & 0.03 & 0.03 & $<0.01$ & $<0.01$ & $<0.01$ & $<0.01$ \\
$\mathrm{Dy}$ & 0.18 & 0.19 & 0.05 & 0.06 & 0.01 & 0.01 \\
$\mathrm{Ho}$ & 0.04 & 0.04 & 0.01 & 0.02 & $<0.01$ & $<0.01$ \\
$\mathrm{Er}$ & 0.10 & 0.10 & 0.04 & 0.04 & $<0.01$ & $<0.01$ \\
$\mathrm{Tm}$ & 0.01 & 0.02 & $<0.01$ & $<0.01$ & $<0.01$ & $<0.01$ \\
$\mathrm{Yb}$ & 0.09 & 0.09 & 0.04 & 0.04 & $<0.01$ & $<0.01$ \\
$\mathrm{Lu}$ & 0.01 & 0.01 & $<0.01$ & $<0.01$ & $<0.01$ & $<0.01$ \\
$\mathrm{Hf}$ & 0.02 & 0.02 & 0.01 & 0.01 & $<0.01$ & 0.01 \\
$\mathrm{~Pb}$ & 0.88 & 0.90 & 0.13 & 0.16 & 0.03 & 0.03 \\
$\mathrm{Th}$ & 0.42 & 0.43 & 0.04 & 0.05 & 0.01 & 0.01 \\
$\mathrm{U}$ & 1.15 & 1.19 & 0.51 & 0.56 & 0.03 & 0.02 \\
\hline & & & & & &
\end{tabular}

Trace elements help us to distinguish between carbonates from different sources, as analysed in this study. L. calcareum $\mathrm{CaCO}_{3}$ showed levels of trace elements around one order of magnitude higher than those of oyster shell and inorganic mineral $\mathrm{CaCO}_{3}$. Among the trace elements analysed, several were below the detection limits for inorganic mineral and oyster shell $\mathrm{CaCO}_{3}$ (Table 4).

Chemical differences between the three samples were related to the mineralogical composition, since L. calcareum $\mathrm{CaCO}_{3}$ was composed of magnesian calcite, calcite and aragonite, while the other two samples of calcium carbonate were composed exclusively of calcite. There are differences in the partition of trace elements between aragonite, low$\mathrm{Mg}$ calcite and high-Mg calcite due to differences between their crystal structures [55]. Figures 8 and 9 show the content of trace elements (ppm) divided by the average composition of the upper terrestrial crust [56], a commonly used form of data representation in geochemistry. Regarding the REE (Figure 8), the L. calcareum $\mathrm{CaCO}_{3}$ sample showed a practically horizontal pattern, indicating that there is no preferential selective incorporation of individual REE. The rare earth patterns of L. calcareum $\mathrm{CaCO}_{3}$, with stable, differ from the composition of seawater, which has depleted cerium levels (negative Ce anomaly) and a trend of increasing amounts of heavy REE [57]. Inorganic elements in seaweeds have two likely sources: elements dissolved in seawater or solid particles in suspension [58]. The similarity of $L$. calcareum $\mathrm{CaCO}_{3}$ to the average of the upper continental crust, in terms of the REE distribution, may suggest that the uptake of suspended solid particles played an important role in the mineralisation of this seaweed. 


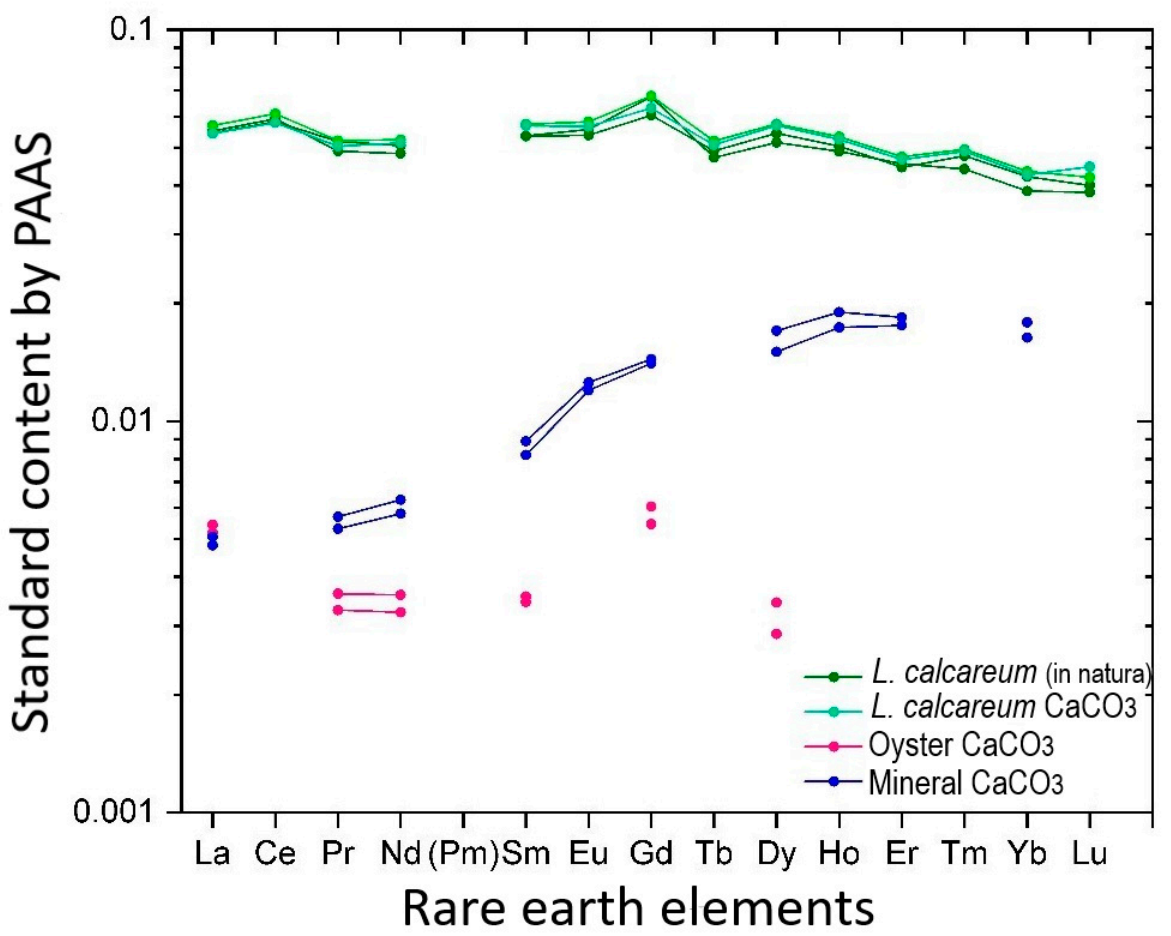

Figure 8. Patterns of rare earth elements (REE) from the three $\mathrm{CaCO}_{3}$ samples, normalised by the average composition of the earth's crust [56].

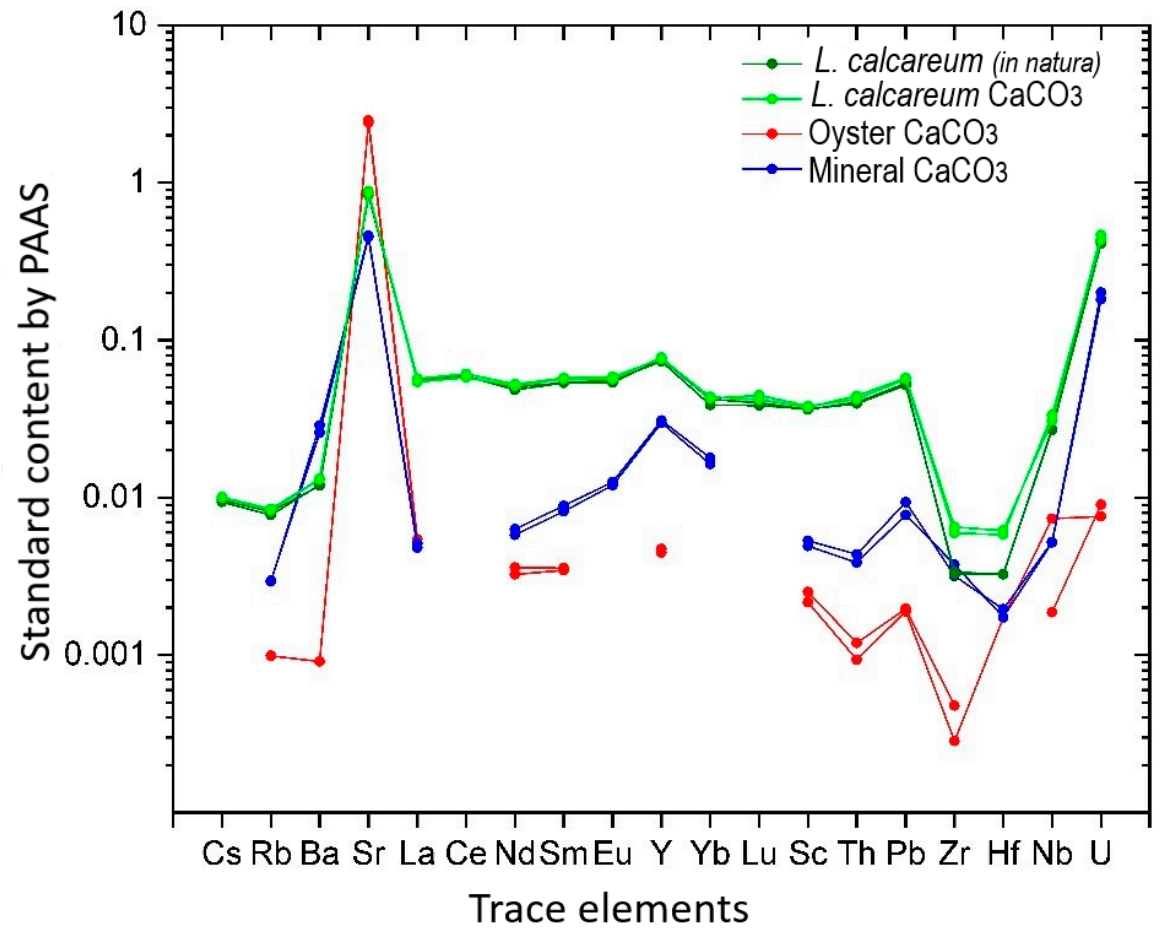

Figure 9. Distribution of trace elements in the three $\mathrm{CaCO}_{3}$ samples, normalised by the average composition of the earth's crust [56].

Inorganic mineral and oyster shell $\mathrm{CaCO}_{3}$ samples had a lower concentration of REE, with several gaps in rare earth patterns due to elements that were below the detection limit, making it difficult to observe trends. Nevertheless, the inorganic mineral $\mathrm{CaCO}_{3}$ sample showed a tendency for the enrichment of medium and heavy rare earth elements $(\mathrm{Eu}-\mathrm{Lu})$ 
compared to light rare earth elements (La-Sm), which is common in marine sediments. The multi-element diagram (Figure 9), where the elements are ordered by their ionic potential (ionic charge/radius), shows that the contents of practically all elements were higher in L. calcareum $\mathrm{CaCO}_{3}$. Exceptions included barium, which was more abundant in inorganic mineral $\mathrm{CaCO}_{3}$, and strontium, which was more abundant in oyster shell $\mathrm{CaCO}_{3}$. Strontium, in particular, was an abundant trace element in all three samples, with levels in the range of hundreds of ppm (Table 4). The reasons are due both to the abundance of this element in natural systems and the similarity of its ionic radius and charge with calcium $\left(\mathrm{Sr}^{2+} \approx \mathrm{Ca}^{2+}\right)$, which allows its uptake into natural calcium carbonates, whether biogenic or otherwise.

The data on the stable carbon and oxygen isotopes (Figure 10) of L. calcareum and oyster shell $\mathrm{CaCO}_{3}$ fall within the category of shallow-water biogenic marine carbonates, with a small fraction in relation to the V-PDB standard (Vienna Pee Dee Belemnite international standard) [59]. Published data on stable isotopes of L. calcareum $\mathrm{CaCO}_{3}$ are rare. Data on carbonate algae (Lithothamnion sp. and Halimeda sp., both composed of calcite and aragonite) were obtained by Rocha [60] in samples collected from the northeast Brazilian coast. The L. calcareum $\mathrm{CaCO}_{3}$ sample analysed in this study is within the compositional group of 66 samples analysed by Rocha [60], who described variations in isotopic ratios in samples of the same species collected at different depths as a consequence of water temperature. Our data on the stable isotopic composition of the oyster shell of Crassostrea virginica is within the isotopic range of oysters found in the James River estuary, Virginia (USA), as published by Grimm et al. [61].

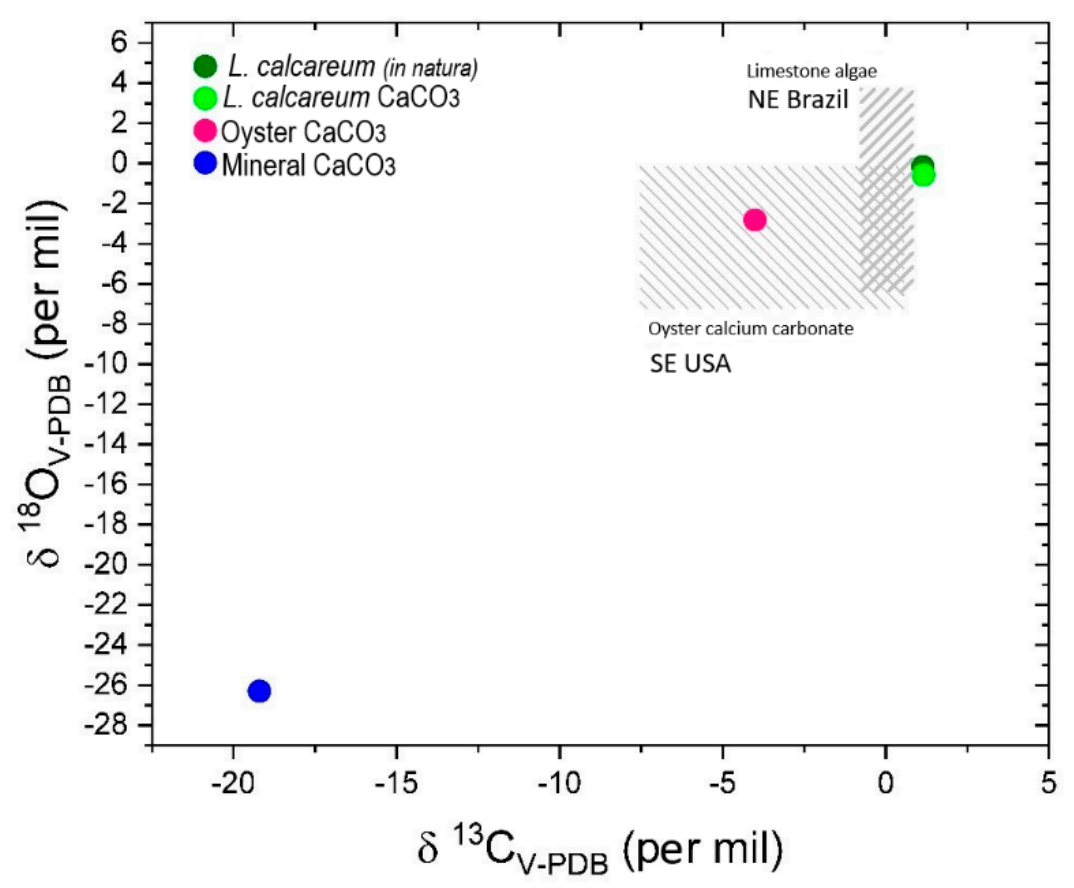

Figure 10. Stable isotopes of carbon $\left(\delta^{13} \mathrm{C}\right)$ and oxygen $\left(\delta^{18} \mathrm{O}\right)$ in the analysed carbonates in reference to the V-PDB standard (Vienna Pee Dee Belemnite international standard) [59]. The hatches indicate the field of isotopic composition of carbonate algae from Northeastern Brazil [60] and oyster shell $\mathrm{CaCO}_{3}$ from the south-eastern coast of the U.S. [61].

Inorganic mineral $\mathrm{CaCO}_{3}$ showed negative carbon $\delta{ }^{13} \mathrm{C}$ and oxygen $\delta{ }^{18} \mathrm{O}$ values. Inorganic mineral $\mathrm{CaCO}_{3}$ is an extra-light carbonate that is used in the pharmaceutical industry. It is chemically precipitated in a controlled process, and its isotopic composition reflects the composition of the raw materials, influenced by the temperature and kinetics of the crystallisation process. 
The small number of isotopic data collected in the present study did not allow us to describe trends, but indicated that the isotopic composition can be used with additional data to distinguish biogenic carbonates. The carbon and oxygen stable isotope ratios of the raw materials are a potential tool for tracing the sources of calcium carbonates that are used in the pharmaceutical industry.

\section{Materials and Methods}

\subsection{Samples}

Calcium carbonate extraction from the seaweed Lithothamnium calcareum occurred mechanically from the harvest at sea, followed by drying. Subsequently, the seaweed was cut so that the crushing was homogeneous and, finally, a raw material was generated in powder form. The powder was micronised for commercial use as L. calcareum $\mathrm{CaCO}_{3}[62,63]$. L. calcareum calcium carbonate was kindly provided by Lithocálcio Indústria, Comércio, Importação, Exportação e Representação Ltd.a. (São Paulo, Brazil), calcium carbonate of inorganic mineral origin was provided by Valdequímica Produtos Químicos Ltd.a. (São Paulo, Brazil) and oyster shell calcium carbonate (Crassostrea virginica) was already processed as a raw material in powder form by Option Fênix Distribuidora de Insumos Ltd.a. (São Paulo, Brazil).

\subsection{Assessment of Powder Flow}

The flow of the powder samples was analysed by determining the apparent density, compacted density, Carr index (CI) and Hausner ratio (HR).

To measure the apparent density $\left(\mathrm{d}_{\mathrm{ap}}\right)$ of the samples, each sample was transferred to a $100 \mathrm{~mL}$ beaker until it reached a volume of $50 \mathrm{~mL}$. Subsequently, the weight was recorded on a semi-analytical scale, and the material was transferred to a standardised cylinder in a Tap Density densimeter (Ethik, São Paulo, Brazil). The compacted density $\left(\mathrm{d}_{\mathrm{cp}}\right)$ was determined as described in the American Pharmacopoeia [64]. From the data obtained, the apparent and compacted density values were calculated as follows:

$$
\begin{aligned}
& \mathrm{d}_{\mathrm{ap}}=\mathrm{M}_{\mathrm{i}} / \mathrm{V}_{\mathrm{i}} \\
& \mathrm{d}_{\mathrm{cp}}=\mathrm{M}_{\mathrm{i}} / \mathrm{V}_{\mathrm{f}}
\end{aligned}
$$

where

$\mathrm{d}_{\mathrm{ap}}=$ apparent density $\left(\mathrm{g} / \mathrm{cm}^{3}\right) ;$
$\mathrm{M}_{\mathrm{i}}=$ initial mass $(\mathrm{g}) ;$
$\mathrm{V}_{\mathrm{i}}=$ initial volume $\left(\mathrm{cm}^{3}\right) ;$
$\mathrm{d}_{\mathrm{cp}}=$ compacted density $\left(\mathrm{g} / \mathrm{cm}^{3}\right) ;$
$\mathrm{V}_{\mathrm{f}}=$ final volume $\left(\mathrm{cm}^{3}\right)$.

The CI and HR were calculated using the values obtained for the apparent density $\left(\mathrm{d}_{\mathrm{ap}}\right.$ and compacted density $\left(\mathrm{d}_{\mathrm{cp}}\right)$, according to the following equations:

$$
\begin{gathered}
C I(\%)=\frac{d_{c p}-d_{a p}}{d_{c p}} \times 100 \\
H R=\frac{d_{c p}}{d_{a p}}
\end{gathered}
$$

where

$\mathrm{CI}=$ Carr index;

$\mathrm{HR}=$ Hausner ratio;

$\mathrm{d}_{\mathrm{cp}}=$ compacted density;

$\mathrm{d}_{\mathrm{ap}}=$ apparent density. 


\subsection{Surface Area and Porosity}

To analyse the surface area and porosity of the samples, a NOVA 2200e gas adsorption analyser (Quantachrome Corporation, Boynton Beach, FL, USA) was used. The samples were desiccated at $90{ }^{\circ} \mathrm{C}$ and then subjected to the test at an equipment temperature between 0 and $-196^{\circ} \mathrm{C}$. The Brunauer-Emmelt-Teller (BET) (Supplementary Materials) method described by Lowell et al. [43] and Klobes et al. [65] was used according to the equations described below. The parameters were programmed in isotherms from 52 points (31 points of adsorption and 21 points of desorption of ultrapure nitrogen gas). Relative pressures $\left(p / p^{0}\right)$ between 0.05 and 0.950 were established, and the analysis time varied from 3 to $8 \mathrm{~h}$.

BET method:

$$
\frac{p / p^{0}}{n\left(1-p / p^{0}\right)}=\frac{1}{n_{m} C}+\frac{C-1}{n_{m} C}\left(p / p^{0}\right)
$$

where

$n=$ amount adsorbed at relative pressure;

$n_{m}=$ specific monolayer capacity;

$\mathrm{C}=$ constant relative to the adsorption of the first monolayer;

$p / p^{0}=$ relative pressure.

Surface area:

$$
A_{(B E T)=n_{m}} \cdot L \cdot a_{m}
$$

where

$A_{(B E T)}=$ BET area;

$L=$ Avogadro constant.

Porosity:

$$
\operatorname{In} P / P_{0}=\frac{-2 \gamma \nabla}{r R T}
$$

where

$r=$ surface tension of the liquid;

$\nabla=$ molar volume of the condensed liquid contained in a narrow pore of radius $r$;

$R=$ gas constant;

$T=$ temperature.

\subsection{Thermal Analysis}

The samples were analysed by thermogravimetry (TG), derived thermogravimetry (DTG) and differential thermal analysis (DTA). Extar TG 7200 equipment (Seiko Instruments, Tokyo, Japan) was used. The selected parameters were an inert nitrogen atmosphere with gas flow $\left(100 \mathrm{~mL} \mathrm{~min}^{-1}\right)$, a heating rate of $10{ }^{\circ} \mathrm{C} \mathrm{min}^{-1}$ and a temperature from 30 to $1000{ }^{\circ} \mathrm{C}$ in a platinum crucible. In addition, the equipment was previously calibrated with a calcium oxalate standard, with the same heating rate and temperature range as those used for the samples.

\subsection{Scanning Electron Microscopy (SEM) and Energy-Dispersive Spectroscopy (EDS)}

The morphology of the samples was analysed at the Technological Characterization Laboratory (Polytechnic School of the University of São Paulo) using a Quanta 650 FEG environmental scanning electron microscope (FEI), equipped with EDS Quantax microanalysis systems (Bruker, MA, USA), image analysis (MLA-Mineral) and a secondary electron detector $x$ Flash 4030 with silicon drift detector (SDD) technology operating under high vacuum conditions. The following instrumental parameters were selected: a $30 \mathrm{~mm}^{2}$ window, and resolutions of $<130 \mathrm{eV}(\mathrm{Mn} \mathrm{K \alpha})$ at $60 \mathrm{kcps}, 138 \mathrm{eV}$ at $130 \mathrm{kcps}$ and $158 \mathrm{eV}$ at 280 kcps. 


\subsection{X-ray Diffraction}

X-ray diffraction analysis (powder method) of the samples was performed at the MultiUser Geoanalytical Center (Institute of Geosciences, University of São Paulo) using a Bruker D8 Advance diffractometer with a LYNXEYE detector (Bruker, MA, USA). The instrumental

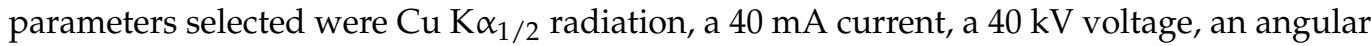
range of $2^{\circ}$ to $65^{\circ}(2 \theta)$, an angular step of $0.02^{\circ}(2 \theta)$ and a scan speed of $38.4 \mathrm{~s}$ per step.

Polymorphs were identified using the High Score Plus 3.0 software (PANalytical B.V., Lelyweg, The Netherlands) and the Crystallography Open Database (COD) [66]. The quantitative analysis of phases in polyphasic samples was performed using the method of Rietveld [67] using the High Score Plus 3.0 program (PANalytical B.V., Lelyweg, The Netherlands).

\subsection{Principal Component Analysis}

The results of the sample characterisation were compared via multivariate analysis and principal component analysis (PCA) with Statistica ${ }^{\mathrm{TM}}$ Inc. software 13.5.0.17 (TIBCO ${ }^{\circledR}$ Software Inc., Tulsa, OK, USA). Powder flow (CI\%), information obtained in the analysis of the surface area by the BET method (specific surface area, size and pore volume), information obtained from the thermal analysis (melting point $\left({ }^{\circ} \mathrm{C}\right)$ and mass loss $(\%)$ ), particle size obtained by SEM and polymorphism were adopted as original variables. After standardising the data, two main components were created, PCA1 and PCA2, which were used in the construction of two-dimensional graphics.

\subsection{Chemical Analysis}

The chemical analysis of trace elements was carried out at the Geoanalytic Multiuser Plant (Instituto de Geosciences, University of São Paulo) using ICP-MS ELAN 6100 DRCTM equipment (PerkinElmer ${ }^{\circledR}$, Waltham, MA, USA), according to the procedures described by Navarro et al. [68].

\subsection{Analysis of Stable Isotopes}

The stable isotopes of carbon $\left(\delta^{13} \mathrm{C}\right)$ and oxygen $\left(\delta^{18} \mathrm{C}\right)$ were analysed at the Research Centre for Geochronology and Isotopic Geochemistry (Institute of Geosciences, University of São Paulo) using a isotopic ratio mass spectrometer (IRMS) Thermo Fisher Scientific ${ }^{\mathrm{TM}}$ -Delta V, Waltham, MA, USA). The isotopic data are presented in the delta $(\delta)$ notation, expressed in per thousand (\%o), which relates each sample's isotopic ratios to those of international reference standards, as shown in the following equations. The accuracy of the $\delta^{13} \mathrm{C}$ results was $0.05 \%$ and the accuracy of the $\delta^{18} \mathrm{O}$ results was $0.07 \%$.

$$
\begin{aligned}
\delta{ }^{18} \mathrm{O}_{\mathrm{V}-\mathrm{PDB}} & =\frac{{ }^{18} \mathrm{O} /{ }^{16} \mathrm{O}_{\text {amostra }}-{ }^{18} \mathrm{O} /{ }^{16} \mathrm{O}_{\mathrm{V}-\mathrm{PDB}}}{{ }^{18} \mathrm{O} /{ }^{16} \mathrm{O}_{\mathrm{V}-\mathrm{PDB}}} \times 1000 \\
\delta^{13} \mathrm{C}_{\mathrm{V}-\mathrm{PDB}} & =\frac{{ }^{13} \mathrm{C} /{ }^{12} \mathrm{C}_{\text {amostra }}-{ }^{13} \mathrm{C} /{ }^{12} \mathrm{C}_{\mathrm{V}-\mathrm{PDB}}}{{ }^{13} \mathrm{C} /{ }^{12} \mathrm{C}_{\mathrm{V}-\mathrm{PDB}}} \times 1000
\end{aligned}
$$

where

${ }^{18} \mathrm{O} /{ }^{16} \mathrm{O}_{\text {sample }}$ and ${ }^{13} \mathrm{C} /{ }^{12} \mathrm{C}_{\text {sample }}=$ isotopic ratios of the samples;

${ }^{18} \mathrm{O} /{ }^{16 \circ}{ }_{\text {V-PDB }}$ and ${ }^{13} \mathrm{C} /{ }^{12} \mathrm{C}_{\mathrm{V}-\mathrm{PDB}}=$ isotopic standards of the Vienna Pee Dee Belemnite international standard.

\section{Conclusions}

In view of the results presented in this study, it is possible to state that seaweed L. calcareum $\mathrm{CaCO}_{3}$ is significantly different in terms of flow properties, surface area, volume and pore size, thermogravimetric profile, morphology, crystalline phases, number of trace elements, rare earth elements and isotopic composition from inorganic mineral and oyster shell $\mathrm{CaCO}_{3}$. All samples analysed in this study have a compromised flow 
due to their anisotropic morphology, which may have an influence on the particle size distribution, hindering tablet production.

L. calcareum $\mathrm{CaCO}_{3}$ is an ultra-microporous material, with a pore size of $<7 \AA$, and has the highest specific surface area $\left(8.1 \mathrm{~m}^{2} \cdot \mathrm{g}^{-1}\right)$ among the studied materials. Thermal events cause similar decomposition and mass loss in the three types of $\mathrm{CaCO}_{3}$, although L. calcareum $\mathrm{CaCO}_{3}$ exhibits DTG $\left(720.3^{\circ} \mathrm{C}\right)$ and DTA $\left(727.3^{\circ} \mathrm{C}\right)$ peaks at a slightly lower temperature compared with other samples. However, the mineralogical composition of L. calcareum $\mathrm{CaCO}_{3}$ includes three phases-aragonite, magnesian calcite and calcite-in contrast to the monomineral composition (calcite) of inorganic mineral and oyster shell $\mathrm{CaCO}_{3}$. The more complex mineralogical composition of the L. calcareum sample leads to a chemical composition that is richer in $\mathrm{Mg}$ and trace elements compared with other samples.

When evaluating the multivariate analysis results, it is possible to clearly distinguish the three sources of $\mathrm{CaCO}_{3}$. All variables (flow properties, surface area, porosity, thermogravimetric profile, morphology and crystalline structures) have an effect, and those that have the greatest effect are calcium content and pore size.

In terms of the chemical composition of L. calcareum $\mathrm{CaCO}_{3}$, trace elements are more evident than in other samples. However, $\mathrm{Al}, \mathrm{Cr}, \mathrm{Se}, \mathrm{Cu}, \mathrm{Mo}, \mathrm{Pb}$ and others are not present in high quantities in any of the samples. In addition, it is possible to distinguish between the trace elements in the studied carbonates. Analysis of stable isotopes of carbon and oxygen clearly distinguishes biogenic $\left(\mathrm{CaCO}_{3}\right.$ from L calcareum and oyster shell) from inorganic mineral calcite, which is enriched in lighter isotopes of carbon and oxygen.

Detailed analysis of $L$. calcareum $\mathrm{CaCO}_{3}$ indicates that this material provides not only $\mathrm{Ca}$, but also $\mathrm{Mg}$ and a wide range of trace elements. By using a combination of analytical techniques, L. calcareum $\mathrm{CaCO}_{3}$ can be clearly distinguished from $\mathrm{CaCO}_{3}$ from other sources used in the pharmaceutical industry, providing a basis for its traceability.

Further studies, such as wet powder rheometry, are needed to determine the best wet granulation conditions for the production of tablets using the Lithothamnium calcareum $\mathrm{CaCO}_{3}$. These studies are ongoing in our laboratory.

Supplementary Materials: The following are available online at https:/ /www.mdpi.com/article/10 $.3390 /$ solids2020013/s1. Figure S1. Multi-Point BET graphs of the Lithothamnium calcareum calcium carbonate sample and data summaries; Figure S2. Multi-Point BET graphs of the inorganic mineral calcium carbonate sample and data summaries; Figure S3. Multi-Point BET graphs of the oyster shell calcium carbonate sample and data summaries; Table S1. Factor coordinates of the variables, based on correlations (Multivariate data); Table S2. Factor coordinates of cases, based on correlations (Multivariate data); Table S3. Eigenvalues of correlation matrix, and related statistics (Multivariate data) Active variables only; Table S4. Factor score coefficients, based on correlations (Multivariate data); Table S5. Summary statistics (Multivariate data); Table S6. Correlations (multivariate data); Table S7. Trace element data from samples normalized by carbonaceous chondrite from A (L. calcareum), B (Inorganic mineral) and $\mathrm{C}$ (oysters shell) $\mathrm{CaCO}_{3}$ samples obtained in ppm values.

Author Contributions: Conceptualization, R.P.d.S. an H.G.F.; methodology, R.P.d.S., G.S.D.K. and V.D.N.B.; investigation, R.P.d.S., G.S.D.K., F.R.D.d.A. and V.D.N.B.; formal analysis, R.P.d.S.; writingoriginal draft, R.P.d.S.; writing, G.S.D.K. and V.D.N.B.; writing-review \& editing, H.G.F. and F.R.D.d.A.; supervision, H.G.F.; project administration, H.G.F. All authors have read and agreed to the published version of the manuscript.

Funding: This research did not receive any specific subsidies from funding agencies in the public, commercial, or non-profit sectors.

Institutional Review Board Statement: Not applicable.

Informed Consent Statement: Not applicable.

Data Availability Statement: The data presented in this study are available in supplementary material.

Acknowledgments: The authors would like to thank the company Lithocalcio Industria, Comércio, Importação \& Exportação Ltd.a, Brazil, for the generous donation of calcium carbonate from the seaweed Lithothamnium calcareum. 
Conflicts of Interest: The authors declare no competing interests.

\section{References}

1. Cabioch, J. Contribution a L'étude Morphologique, Anatomique et Systématique de deux Mélobésiécs: Lithothamnium calcarenm (Pallas) Areschoug et Lithothamnium corallioides Crouan. Bot. Mar. 1969, 9, 33-53. [CrossRef]

2. Pouget, E.; Bomans, P.; Goos, J.; Frederik, P.; De With, G.; Sommerdijk, N. The Initial Stages of Template-Controlled CaCO 3 Formation Revealed by Cryo-TEM. Science 2009, 323, 1455-1458. [CrossRef] [PubMed]

3. Wysokowski, M.; Machałowski, T.; Petrenko, I.; Schimpf, C.; Rafaja, D.; Galli, R.; Ziętek, J.; Pantović, S.; Voronkina, A.; Kovalchuk, V.; et al. 3D Chitin Scaffolds of Marine Demosponge Origin for Biomimetic Mollusk Hemolymph-Associated Biomineralization Ex-Vivo. Mar. Drugs 2020, 18, 123. [CrossRef] [PubMed]

4. Ehrlich, H.; Martinović, R.; Joksimović, D.; Petrenko, I.; Schiaparelli, S.; Wysokowski, M.; Tsurkan, D.; Stelling, A.L.; Springer, A.; Gelinsky, M.; et al. Conchixes: Organic scaffolds which resemble the size and shapes of mollusks shells, their isolation and potential multifunctional applications. Appl. Phys. A 2020, 126, 562. [CrossRef]

5. MacKenzie, F.T.; Morse, J.W. Sedimentary carbonates through Phanerozoic time. Geochim.Cosmochim. Acta 1992, 56, 3281-3295. [CrossRef]

6. Durand, N.; Monger, H.C.; Canti, M.G. Calcium Carbonate Features. In Interpretation of Micromorphological Features of Soils and Regoliths; Elsevier: Amsterdam, The Netherlands, 2010; pp. 149-194.

7. Nielsen, P.; Baciocchi, R.; Costa, G.; Quaghebeur, M.; Snellings, R. Carbonate-bonded construction materials from alkaline residues. RILEM Tech. Lett. 2017, 2, 53-58. [CrossRef]

8. Morse, J.W.; Arvidson, A.R.S.; Lüttge, A. Calcium Carbonate Formation and Dissolution. Chem. Rev. 2007, 107, 342-381. [CrossRef]

9. Al Omari, M.; Rashid, I.; Qinna, N.; Jaber, A.; Badwan, A. Calcium Carbonate. Profiles Drug Subst. Excip. Relat. Methodol. 2016, 41, 31-132. [CrossRef]

10. Dizaj, S.M.; Barzegar-Jalali, M.; Zarrintan, M.H.; Adibkia, K.; Lotfipour, F. Calcium carbonate nanoparticles as cancer drug delivery system. Expert Opin. Drug Deliv. 2015, 12, 1649-1660. [CrossRef]

11. Jimoh, O.A.; Ariffin, K.S.; Bin Hussin, H.; Temitope, A.E. Synthesis of precipitated calcium carbonate: A review. Carbonates Evaporites 2018, 33, 331-346. [CrossRef]

12. Borrego-Sánchez, A.; Sánchez-Espejo, R.; Albertini, B.; Passerini, N.; Cerezo, P.; Viseras, C.; Sainz-Díaz, C.I. Ground Calcium Carbonate as a Low Cost and Biosafety Excipient for Solubility and Dissolution Improvement of Praziquantel. Pharmaceutics 2019, 11, 533. [CrossRef]

13. Golob, A.L.; Laya, M.B. Osteoporosis Screening, Prevention and Management. Med. Clin. N. Am. 2015, 99, 587-606. [CrossRef]

14. Nakamura, Y.; Suzuki, T.; Kamimura, M.; Murakami, K.; Ikegami, S.; Uchiyama, S.; Kato, H. Vitamin D and calcium are required at the time of denosumab administration during osteoporosis treatment. Bone Res. 2017, 5, 17021. [CrossRef]

15. Langdahl, B.L. New treatments of osteoporosis. Osteoporos. Sarcopenia 2015, 1, 4-21. [CrossRef]

16. Costa, A.L.D.; Da Silva, M.A.C.N.; Nascimento, A.C.B.; Barbosa, M.D.C.L.; Batista, J.E.; Bezerra, G.F.D.B.; Brito, L.M.O.; Viana, G.M.D.C.; Filho, W.E.M.; Vidal, F.C.B.; et al. Osteoporose na atenção primária: Uma oportunidade para abordar os fatores de risco. Rev. Bras.Reum. 2016, 56, 111-116. [CrossRef]

17. Markl, D.; Wang, P.; Ridgway, C.; Karttunen, A.-P.; Chakraborty, M.; Bawuah, P.; Pääkkönen, P.; Gane, P.; Ketolainen, J.; Peiponen, K.-E.; et al. Characterization of the Pore Structure of Functionalized Calcium Carbonate Tablets by Terahertz TimeDomain Spectroscopy and X-Ray Computed Microtomography. J. Pharm. Sci. 2017, 106, 1586-1595. [CrossRef]

18. Nguyen, M.H.T.; Jung, W.-K.; Kim, S.-K. Marine Algae Possess Therapeutic Potential for Ca-Mineralization via Osteoblastic Differentiation. Adv. Food Nutr. Res. 2011, 64, 429-441. [CrossRef]

19. Brennan, O.; Stenson, B.; Widaa, A. Incorporation of the natural marine multi-mineral dietary supplement Aquamin enhances osteogenesis and improves the mechanical properties of a collagen-based bone graft substitute. J. Mech. Behav. Biomed. Mater. 2015, 47, 114-123. [CrossRef]

20. Bailey, J.C. Molecular Systematics of Red Algae. Ph.D. Thesis, Louisiana State University and Agricultural \& Mechanical College, Baton Rouge, LA, USA, 1996; pp. 40-44. Available online: https://digitalcommons.lsu.edu/gradschool_disstheses/6316 (accessed on 20 May 2019).

21. Almeida, F.; Schiavo, L.; Vieira, A.; Araújo, G.; Queiroz-Junior, C.; Teixeira, M.; Cassali, G.; Tagliati, C. Gastroprotective and toxicological evaluation of the Lithothamnion calcareum algae. Food Chem. Toxicol. 2012, 50, 1399-1404. [CrossRef]

22. Desideri, D.; Cantaluppi, C.; Ceccotto, F.; Meli, M.A.; Roselli, C.; Feduzi, L. Essential and toxic elements in seaweeds for human consumption. J. Toxicol. Environ. Health Part A 2016, 79, 112-122. [CrossRef]

23. Assoumani, M.B. AquaMin, a natural calcium supplement derived from seaweed. Agro Food Ind. Hi-Tech 1997, 8, 45-47.

24. Aslam, M.N.; Kreider, J.M.; Paruchuri, T.; Bhagavathula, N.; DaSilva, M.; Zernicke, R.F.; Goldstein, S.A.; Varani, J. A MineralRich Extract from the Red Marine Algae Lithothamnion calcareum Preserves Bone Structure and Function in Female Mice on a Western-Style Diet. Calcif. Tissue Int. 2010, 86, 313-324. [CrossRef]

25. Uenishi, K.; Tokiwa, M.; Kato, S.; Shiraki, M. Stimulation of intestinal calcium absorption by orally administrated vitamin D3 compounds: A prospective open-label randomized trial in osteoporosis. Osteoporos. Int. 2018, 29, 723-732. [CrossRef] 
26. López-Benito, M. Estudio de la composición química del Lithothamnium calcareum (Aresch) y su aplicación como corrector de terrenos de cultivo. Inv. Pesq. 1963, 23, 53-70.

27. Déléris, P.; Nazih, H.; Bard, J.-M. Seaweeds in Human Health. In Seaweed in Health and Disease Prevention; Elsevier BV: Amsterdam, The Netherlands, 2016; pp. 319-367.

28. Bang, J.-H.; Jang, Y.N.; Kim, W.; Song, K.S.; Jeon, C.W.; Chae, S.C.; Lee, S.-W.; Park, S.-J.; Lee, M.G. Specific surface area and particle size of calcium carbonate precipitated by carbon dioxide microbubbles. Chem. Eng. J. 2012, 198-199, 254-260. [CrossRef]

29. Glibert, P.M.; Middelburg, J.J.; McClelland, J.W.; Zanden, M.J.V. Stable isotope tracers: Enriching our perspectives and questions on sources, fates, rates, and pathways of major elements in aquatic systems. Limnol. Oceanogr. 2019, 64, 950-981. [CrossRef]

30. Jasper, J.P. The increasing use of stable isotopes in the pharmaceutical industry. Pharm. Technol. 1999, 23, 106-114.

31. Cristea, G.; Magdas, D.A.; Voica, C.; Feher, I. Stable Isotope Fingerprinting for Pharmaceutical Authentication. Anal. Lett. 2017, 50, 2691-2698. [CrossRef]

32. Hadjittofis, E.; Das, S.; Zhang, G.; Heng, J. Interfacial Phenomena. In Developing Solid Oral Dosage Forms: Pharmaceutical Theory and Practice, 2nd ed.; Academic press: Cambridge, MA, USA, 2017; pp. 225-252. [CrossRef]

33. Cabiscol, R.; Finke, J.H.; Zetzener, H.; Kwade, A. Characterization of Mechanical Property Distributions on Tablet Surfaces. Pharmaceutics 2018, 10, 184. [CrossRef] [PubMed]

34. Sherrington, L.A.; Sherrington, A. Guaifenesin. Anal. Profiles Drug Subst. 1998, 25, 121-164.

35. Kaerger, J.; Edge, S.; Price, R. Influence of particle size and shape on flowability and compactibility of binary mixtures of paracetamol and microcrystalline cellulose. Eur. J. Pharm. Sci. 2004, 22, 173-179. [CrossRef]

36. Huang, Z.; Scicolone, J.V.; Han, X.; Davé, R.N. Improved blend and tablet properties of fine pharmaceutical powders via dry particle coating. Int. J. Pharm. 2015, 478, 447-455. [CrossRef]

37. Sun, C.C. Quantifying effects of moisture content on flow properties of microcrystalline cellulose using a ring shear tester. Powder Technol. 2016, 289, 104-108. [CrossRef]

38. Anovitz, L.M.; Cole, D.R. Characterization and Analysis of Porosity and Pore Structures. Rev. Miner. Geochem. 2015, 80, 61-164. [CrossRef]

39. Kurig, H.; Russina, M.; Tallo, I.; Siebenbürger, M.; Romann, T.; Lust, E. The suitability of infinite slit-shaped pore model to describe the pores in highly porous carbon materials. Carbon 2016, 100, 617-624. [CrossRef]

40. Ahuja, G.; Pathak, K. Porous carriers for controlled/modulated drug delivery. Indian J. Pharm. Sci. 2009, 71, 599-607. [CrossRef]

41. Schüth, F.; Sing, K.S.W.; Weitkamp, J. Handbook of Porous Solids; Wiley: Weinheim, Germany, 2002; p. 3207. [CrossRef]

42. Thommes, M.; Kaneko, K.; Neimark, A.V.; Olivier, J.P.; Rodriguez-Reinoso, F.; Rouquerol, J.; Sing, K.S. Physisorption of gases, with special reference to the evaluation of surface area and pore size distribution (IUPAC Technical Report). Pure Appl. Chem. 2015, 87, 1051-1069. [CrossRef]

43. Lowell, S.; Shields, J.E.; Thomas, M.A.; Thommes, M. Characterization of Porous Solids and Powders: Surface Area, Pore Size and Density; Springer: Berlin/Heidelberg, Germany, 2004.

44. Xia, X.; Chen, J.; Shen, J.; Huang, D.; Duan, P.; Zou, G. Synthesis of hollow structural hydroxyapatite with different morphologies using calcium carbonate as hard template. Adv. Powder Technol. 2018, 29, 1562-1570. [CrossRef]

45. D’Elia, A.; Pinto, D.; Eramo, G.; Giannossa, L.; Ventruti, G.; Laviano, R. Effects of processing on the mineralogy and solubility of carbonate-rich clays for alkaline activation purpose: Mechanical, thermal activation in red/ox atmosphere and their combination. Appl. Clay Sci. 2018, 152, 9-21. [CrossRef]

46. Li, X.-G.; Lv, Y.; Ma, B.-G.; Wang, W.-Q.; Jian, S.-W. Decomposition kinetic characteristics of calcium carbonate containing organic acids by TGA. Arab. J. Chem. 2017, 10, S2534-S2538. [CrossRef]

47. Thriveni, T.; Um, N.; Nam, S.-Y.; Ahn, Y.J.; Han, C.; Ahn, J.W. Factors Affecting the Crystal Growth of Scalenohedral Calcite by a Carbonation Process. J. Korean Ceram. Soc. 2014, 51, 107-114. [CrossRef]

48. Ukrainczyk, M.; Gredičak, M.; Jerić, I.; Kralj, D. Interactions of Scalenohedral Calcite Crystals with Acidic Amino Acid Derivatives of Salicylic Acid. Cryst. Growth Des. 2014, 14, 4335-4346. [CrossRef]

49. Long, X.; Ma, Y.; Qi, L. Biogenic and synthetic high magnesium calcite-A review. J. Struct. Biol. 2014, 185, 1-14. [CrossRef] [PubMed]

50. Rattanachaiwong, S.; Singer, P. Diets and Diet Therapy: Trace Elements. Encycl. Food Secur. Sustain. 2019, 2, 143-160. [CrossRef]

51. Cannas, D.; Loi, E.; Serra, M.; Firinu, D.; Valera, P.; Zavattari, P. Relevance of Essential Trace Elements in Nutrition and Drinking Water for Human Health and Autoimmune Disease Risk. Nutrients 2020, 12, 2074. [CrossRef]

52. Mehri, A. Trace Elements in Human Nutrition (II)—An Update. Int. J. Prev. Med. 2020, 11, 2. [CrossRef]

53. World Health Organization. Trace Elements in Human Nutrition and Health. World Health Organization: Geneva, Switzerland, 1996; p. 360. Available online: https:/ / www.who.int/nutrition/publications/micronutrients/9241561734/en/ (accessed on 4 August 2020).

54. EFSA (European Food Safety Authority) Panel on Dietetic Products Nutrition \& Allergies. Dietary Reference Values for Nutrients. Summ. Rep. EFSA Support. Publ. 2017, 14, e15121. [CrossRef]

55. Veizer, J. Chapter 8. Trace Elements and Isotopes in Sedimentary Carbonates. Rev. Mineral. Geochem. 1983, 11, 265-300. [CrossRef]

56. Taylor, S.R.; Mclennan, S.M. The Continental Crust: Its Composition and Evolution; Blackwell: Oxford, UK, $1985 ;$ p. 298.

57. Zhu, Y. Determination of rare earth elements in seawater samples by inductively coupled plasma tandem quadrupole mass spectrometry after coprecipitation with magnesium hydroxide. Talanta 2020, 209, 120536. [CrossRef] 
58. Fu, F.F.; Akagi, T.; Yabuki, S.; Iwaki, M.; Ogura, N. Distribution of rare earth elements in seaweed: Implication of two different sources of rare earth elements and silicon in seaweed. J. Phycol. 2000, 36, 62-70. [CrossRef]

59. Sharp, Z. Principles of Stable Isotope Geochemistry; Prentice Hall: Hoboken, NJ, USA, 2006; p. 344.

60. Rocha, C.M.S. Estudo Químico de Lithothamnion sp. e Halimeda sp. no Nordeste Brasileiro. Tese (Doutorado em GeologiaHidrogeologia e Recursos Minerais). Universidade Federal do Ceará: Fortaleza, Brazil, 2013. Available online: http:/ /www. repositorio.ufc.br/bitstream/riufc/15684/1/2013_tese_cmsrocha.pdf (accessed on 14 May 2020).

61. Grimm, B.L.; Spero, H.J.; Harding, J.M.; Guilderson, T.P. Seasonal radiocarbon reservoir ages for the 17th century James River, Virginia estuary. Quat. Geochronol. 2017, 41, 119-133. [CrossRef]

62. Vilain, J. Improvements Relating to Seaweed-Derived Preparations. Depositante: Keith W.. Nash \& CO. WO1992011020A1. Depósito: 17 dez. 1991. Concessão: 9 Jul. 1992. Available online: https://patents.google.com/patent/WO1992011020A1/en (accessed on 5 December 2020).

63. Mendes, C.M. Process for Producing a Marine Mineral Concentrate Made from Lithothamnium Seaweed, and the Marine Mineral Concentrate Obtained Therefrom. Depositante: PHOSTHER ALGAMAR Ltd.a. US20130266655A1. Depósito: 9 abr. 2012. Available online: https:/ / patents.google.com/patent/US20130266655A1/en (accessed on 28 November 2020).

64. United States Pharmacopeia National Formulary, 42nd ed.; United States Pharmacopeial Convention: Rockville, ML, USA, 2019.

65. Klobes, P.; Meyer, K.; Munro, G. Porosity and Specific Surface Area Measurements for Solid Materials; National Institute of Standards and Technology: Gaithersburg, ML, USA, 2006; p. 89.

66. COD. Crystallography Open Database. Available online: http://www.crystallography.net/cod/ (accessed on 28 August 2020).

67. Rietveld, H.M. A profile refinement method for nuclear and magnetic structures. J. Appl. Crystallogr. 1969, 2, 65-71. [CrossRef]

68. Navarro, M.S.; Andrade, S.; Ulbrich, H.H.G.J.; Gomes, C.D.B.; Girardi, V.A.V. The Direct Determination of Rare Earth Elements in Basaltic and Related Rocks using ICP-MS: Testing the Efficiency of Microwave Oven Sample Decomposition Procedures. Geostand. Geoanal. Res. 2008, 32, 167-180. [CrossRef] 